Research Article

\title{
Matrine Exerts Hepatotoxic Effects via the ROS-Dependent Mitochondrial Apoptosis Pathway and Inhibition of Nrf2- Mediated Antioxidant Response
}

\author{
Longtai You, ${ }^{1}$ Chunjing Yang, ${ }^{1}$ Yuanyuan Du, ${ }^{1}$ Yi Liu, ${ }^{1}$ Gongsen Chen, ${ }^{1}$ Na Sai, ${ }^{1}$ \\ Xiaoxv Dong $\mathbb{D},{ }^{1}$ Xingbin Yin $\mathbb{D}^{1}$, and Jian $\mathrm{Ni} \mathbb{D}^{2}$ \\ ${ }^{1}$ School of Chinese Materia Medica, Beijing University of Chinese Medicine, Beijing 100029, China \\ ${ }^{2}$ Beijing Research Institute of Chinese Medicine, Beijing University of Chinese Medicine, Beijing 100029, China
}

Correspondence should be addressed to Xiaoxv Dong; 20150941174@bucm.edu.cn, Xingbin Yin; yxbtcm@163.com, and Jian Ni; njtcm@263.net

Received 16 April 2019; Revised 14 July 2019; Accepted 31 August 2019; Published 14 October 2019

Academic Editor: Manuela Corte-Real

Copyright ( 2019 Longtai You et al. This is an open access article distributed under the Creative Commons Attribution License, which permits unrestricted use, distribution, and reproduction in any medium, provided the original work is properly cited.

\begin{abstract}
Matrine, an alkaloid isolated from Sophora flavescens, possesses a wide range of pharmacological properties. However, the use of matrine in clinical practice is limited due to its toxic effects. The present study investigated the roles of mitochondria and reactive oxygen species (ROS) in matrine-induced liver injury. Our results showed that treatment of HL-7702 cells with matrine led to significant and concentration- and time-dependent reductions in their viability, as well as significant and concentrationdependent increases in the number of apoptotic cells and supernatant lactate dehydrogenase (LDH) activity. The treatment led to significant increases in the population of cells in S phase and significant reduction of cell proportion in G0/G1 and G2/M phases. It also significantly and concentration-dependently increased the levels of ROS and malondialdehyde (MDA) but significantly and concentration-dependently reduced superoxide dismutase (SOD) activity, level of reduced glutathione (GSH), and mitochondrial membrane potential (MMP). Matrine treatment significantly and concentration-dependently upregulated the expressions of Bax, p53, p-p53, p21, cyclin E, Fas, cleaved caspase-3, caspase-8, and caspase-9 proteins and downregulated the expressions of $\mathrm{Bcl}-2$, cyclin-dependent kinase 2 (CDK2), and cyclin A. It also significantly promoted the cleavage of poly(ADP-ribose)polymerase (PARP), upregulated Kelch-like ECH-associated protein 1 (Keap1) expression, and downregulated the expressions of cellular total and nuclear Nrf2. Matrine significantly inhibited the expressions of downstream oxidoreductases (Heme oxygenase-1 (HO-1) and NAD(P)H:quinone oxidoreductases 1 (NQO-1)) and enhanced the formation of Keap1/Nrf2 protein complex. These results show that the hepatotoxic effect of matrine is exerted via inhibition of Nrf2 pathway, activation of ROS-mediated mitochondrial apoptosis pathway, and cell cycle arrest at $\mathrm{S}$ phase. Pretreatment with $\mathrm{N}$-acetyl cysteine (NAC) partially reversed matrine-induced hepatotoxicity.
\end{abstract}

\section{Introduction}

Matrine (dodecahydro3a,7a-diaza-benzo[de]anthracen-8-one) (Figure 1) is an alkaloid isolated from the dry root of Sophora flavescens, a plant indigenous to China [1]. In vitro studies have shown that matrine possesses a wide range of pharmacological effects, such as anticancer, anti-inflammatory, antibacterial, antiparasitic, antivirus, and antifibrosis properties [2-4]. In Traditional Chinese Medicine (TCM), matrine is used to treat hepatitis, cardiac diseases, skin diseases, and some cancers [5]. It inhibits the proliferation of cancer cells, such as HepG2, Bel7402, HT29, and K562 cells. The involvement of proteins, such as $\mathrm{Bax} / \mathrm{Bcl}-2$, Fas/Fas-L, caspase-3, AKT, and JAK2/STAT3, in matrine-induced apoptosis has been reported [6-10]. Reports on the side effects of matrine have increased considerably, and this has limited its use in clinical practice. Studies have shown that matrine exerts hepatotoxic and neurotoxic effects in zebrafish embryos/larvae $[11,12]$. In one study, it was reported that treatment with matrine resulted in severe liver damage in mice [13]. 


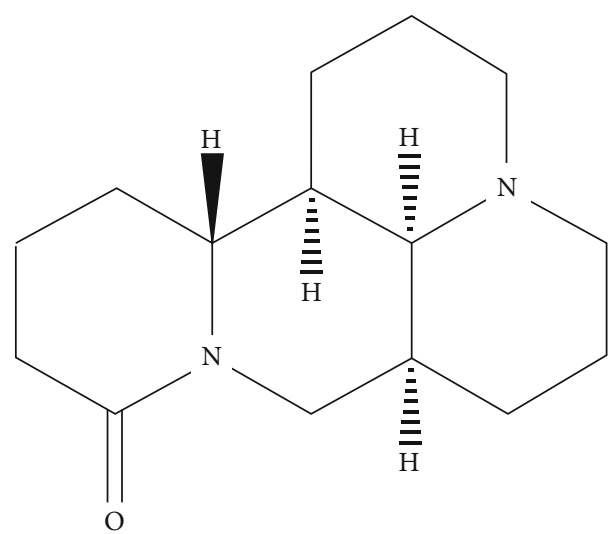

FIGURE 1: The chemical structure of matrine.

However, another study reported that matrine had no significant effect on the viability of HL-7702 cells or body weight of mice, suggesting that it may not be hepatotoxic [14]. Thus, there appears to be confusion about the hepatotoxic effect of matrine, while the underlying mechanism of its toxicity has not been fully elucidated.

Stimulation of cells by xenobiotics or drugs results in the overproduction of ROS and thus oxidative stress. The association of ROS with drug-induced hepatotoxicity is an indication that oxidative stress is one of the major causes of hepatocyte apoptosis and liver dysfunction [15-18]. The activation of nuclear factor-erythroid 2-related factor 2 (Nrf2) has been linked to drug-induced hepatotoxicity [19]. After the translocation of Nrf2 to the nucleus, it interacts with antioxidant response elements (ARE) to modulate intracellular antioxidant responses [20]. Under normal physiological conditions, Nrf2 coexists with Keap1 in the cytosol, and Keap1 directly interacts with Nrf2 to prevent its translocation from the cytosol to the nucleus. High cellular levels of ROS activate the dissociation of Nrf2 from Keap1 and its subsequent transfer to the nucleus. While in the nucleus, Nrf2 binds to ARE and activates the expressions of oxidoreductases such as $\gamma$ glutamyl cysteine synthetase catalytic subunit (GCLC), HO1 , and NQO-1, resulting in manifestation of its antioxidant effects [21]. Thus, the Nrf2 pathway is considered a major factor regulatory mechanism for reducing oxidative stress.

Apoptosis is a physiological process of autonomous, regulated cell death in response to disease and exogenous stress. It is regulated by two major pathways: receptor-mediated pathway (extrinsic pathway) and mitochondrial-dependent pathway (intrinsic pathway) $[22,23]$. Caspases are a family of cysteine proteases which play key roles in cell apoptosis [24]. The extrinsic pathway is initiated by ligation of death receptors and subsequent activation of caspase- 8 within a death-inducing signaling complex. On the other hand, the intrinsic pathway is triggered by intracellular stress and subsequent activation by caspase-9. Although both pathways can be activated by various stimuli, both lead to direct activation of downstream effector caspase-3 $[25,26]$. The increased production of ROS leads to induction of mitochondrialdependent apoptosis [27]. Studies have shown that high intracellular levels of ROS result in mitochondrial DNA damage and release of cytochrome $c$ from mitochondria to cytosol, thereby triggering caspase-dependent or caspaseindependent apoptosis $[28,29]$.

The HL-7702 cells isolated from a normal human liver exhibit ultrastructural features similar to those of hepatic carcinoma. These cells are useful for assessing druginduced hepatotoxicity and constitute an ideal in vitro model for cytotoxicity studies $[30,31]$. The present study investigated the roles of mitochondria and ROS in matrine-induced liver injury.

\section{Materials and Methods}

2.1. Reagents. The HL-7702 cell line was purchased from China Infrastructure of Cell Line Resources. Matrine (batch no. MUST-17030401, purity $>98.72 \%$ ) was a product of Chengdu Mansite Bio-Technology Co., Ltd. (Chengdu, China). Dulbecco's modified Eagle's medium (DMEM), FBS, trypsin, penicillin, and streptomycin solutions were obtained from Corning (NY, USA), and dimethyl sulfoxide (DMSO), phosphate-buffered saline (PBS), and 3-(4,5dimethyl thiazol-2-yl-)-2,5-diphenyl tetrazolium bromide (MTT) were products of Solarbio (Beijing, China). Assay kits for SOD, MDA, and GSH were purchased from Nanjing Jiancheng Bioengineering Institute (Nanjing, China). Assay kits for Annexin V-fluorescein isothiocyanate (FITC)/propidium iodide (PI) apoptosis, 4',6-diamidino-2-phenylindole (DAPI), LDH, MMP, ROS, cell cycle, and bicinchoninic acid (BCA) were purchased from Beyotime (Shanghai, China). Polyclonal antibodies for Fas, Bax, Bcl-2, p53, p-p53 (Ser-15), p21, cyclin A, CDK 2, cytochrome $c$, caspase-3, caspase-9, PARP, cleaved caspase-3, cleaved caspase-9, cleaved PARP, Nrf2, Keap1, HO-1, and NQO1 were products of Cell Signaling Technology (USA). Antibodies for caspase8 and cleaved caspase- 8 were purchased from Abcam (UK). A microplate reader was obtained from Thermo Fisher Scientific Co., Ltd. (USA), and a flow cytometer was the product of BD Biosciences (USA). The ProteoExtract ${ }^{\circledR}$ Cytosol/Mitochondria Fractionation kit was purchased from Millipore (USA), while a protease inhibitor was obtained from SigmaAldrich (USA).

2.2. Cell Cultures and Treatment. The HL-7702 cells were cultured in DMEM supplemented with 10\% FBS and 1\% penicillin/streptomycin at $37^{\circ} \mathrm{C}$ in a humidified atmosphere of $5 \%$ $\mathrm{CO}_{2}$ and $95 \%$ air. After attaining $80-90 \%$ confluence, the cells were treated with serum-free medium and graded concentrations of matrine $(0-4 \mathrm{mg} / \mathrm{mL})$ for $24 \mathrm{~h}$. Normal cell culture without matrine served as the control group. Cells in the logarithmic growth phase were selected and used in this study.

2.3. Cell Viability Assay. The effect of matrine on the viability of HL-7702 cells was assessed using the MTT assay. The cells $\left(5.0 \times 10^{3}\right.$ cells/well $)$ were seeded in 96-well plates and cultured in DMEM for $24 \mathrm{~h}$. Matrine $(0-4 \mathrm{mg} / \mathrm{mL})$ was added to the cells, followed by incubation for $72 \mathrm{~h}$. At the end of the third day, $20 \mu \mathrm{L}$ of $5 \mathrm{~g} / \mathrm{L}$ MTT solution was added to the wells, followed by incubation for another $4 \mathrm{~h}$. The medium was finally replaced with $150 \mathrm{~mL}$ of $0.1 \%$ DMSO solution, 
agitated at 50 oscillations/min for $10 \mathrm{~min}$ to completely dissolve the formazan crystals formed, and absorbance of the samples was read in a microplate reader at $570 \mathrm{~nm}$. The degree of cell proliferation was determined at different time points: 24,48 , and $72 \mathrm{~h}$. The assay was performed in triplicate. Cell viability was calculated as follows:

Cell viability $(\%)=\frac{\text { Absorbance of the experimental group }}{\text { Absorbance of the control group }} \times 100$.

2.4. Determination of Activity of $L D H$. The cells were seeded into 96-well plates at a density of $1.5 \times 10^{4}$ cells/well and cultured in DMEM for $24 \mathrm{~h}$. Matrine $(0-4 \mathrm{mg} / \mathrm{mL})$ was added to the cells and incubated for $48 \mathrm{~h}$. Then, the cells were trypsinized and the resultant cell suspension centrifuged at $3000 \mathrm{rpm}$ for $10 \mathrm{~min}$ to obtain supernatant. The activity of each well was harvested, and LDH activity was determined in the supernatant using the $\mathrm{LDH}$ kit according to the instructions on the kit manual.

2.5. DAPI Staining. Morphological changes in the nuclei of cells can be visually analyzed by staining DNA with DAPI fluorescent dye [32]. The cells were seeded at a density of 4 $\times 10^{5}$ cells/well in 6-well plates and treated with graded concentrations of matrine $(0-4 \mathrm{mg} / \mathrm{mL})$ for $48 \mathrm{~h}$ prior to staining. Then, the cells were harvested, washed twice with PBS, and fixed with $4 \%$ paraformaldehyde for $20 \mathrm{~min}$ at room temperature. They were thereafter stained with DAPI solution in the dark for $10 \mathrm{~min}$ at room temperature. Changes in the nuclei of stained cells were observed under an inverted Olympus IX71 fluorescence microscope and photographed. The apoptotic cells were identified.

2.6. Apoptosis Analysis. The cells were seeded in 6-well plates at a density of $4 \times 10^{5}$ cells/well and cultured for $24 \mathrm{~h}$. Then, matrine at different concentrations $(0-4 \mathrm{mg} / \mathrm{mL})$ was added to the medium and incubated for another $48 \mathrm{~h}$ at $37^{\circ} \mathrm{C}$ in the presence or absence of NAC. The cells were thereafter washed with PBS and thoroughly mixed with $295 \mu \mathrm{L}$ binding buffer. Subsequently, the cells were stained with $5 \mu \mathrm{L}$ each of Annexin V-fluorescein isothiocyanate and propidium iodide within $25 \mathrm{~min}$ at room temperature in the dark. Cell apoptosis was assessed using a flow cytometer fitted with argon laser operated at $485 \mathrm{~nm}$ [33].

2.7. Measurement of Intracellular ROS. The levels of ROS in HL-7702 cells were determined using the 2,7-dichlorofluorescin diacetate (DCFH-DA) assay. The cells treated with matrine $(0-4 \mathrm{mg} / \mathrm{mL})$ were washed with PBS after an initial incubation period of $48 \mathrm{~h}$. Then, $10 \mu \mathrm{M}$ solution of DCFHDA was added to the plates and incubated for another $30 \mathrm{~min}$ at $37^{\circ} \mathrm{C}$. Thereafter, the cells were washed with PBS and injected into the flow cytometer for analysis [34].

2.8. Measurement of Lipid Peroxidation. The HL-7702 cells were seeded in 6 -well plates at a density of $4 \times 10^{5}$ cells/well and cultured for $24 \mathrm{~h}$. After treatment with graded concentrations of matrine for $48 \mathrm{~h}$, the cells were lysed with ice-cold radio-immunoprecipitation assay (RIPA) buffer and centrifuged at $12,000 \mathrm{rpm}$ for $10 \mathrm{~min}$ at $4^{\circ} \mathrm{C}$. The level of MDA was determined in the supernatant using the MDA assay kit [35].

2.9. Determination of Oxidative Status in the Cells. The HL-7702 cells were seeded in 6-well plates at a density of $4 \times 10^{5}$ cells/well and cultured for $24 \mathrm{~h}$. After treatment with graded concentrations of matrine for $48 \mathrm{~h}$, the activity of SOD and level of GSH were determined using their respective assay kits $[36,37]$.

2.10. Determination of Effect of Matrine on MMP. Following $24 \mathrm{~h}$ culturing of the HL-7702 cells seeded in 6-well plates at a density of $4 \times 10^{5}$ cells/well, the cells were treated with graded concentrations of matrine for $48 \mathrm{~h}$

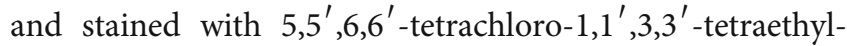
benzimidazolylcarbocyanine iodide (JC-1) working solution $(10 \mu \mathrm{M})$ for $30 \mathrm{~min}$ at $37^{\circ} \mathrm{C}$ in the dark. Thereafter, they were washed thrice with PBS and subjected to flow cytometric analysis.

2.11. Cell Cycle Analysis. The effect of matrine on the distribution of HL-7702 cells among different phases of the cell cycle was determined using a flow cytometer [38]. The treatment of the cells is referred to under Section 2.9. The cells were then washed with PBS and fixed with $70 \%$ ethyl alcohol at $4^{\circ} \mathrm{C}$ overnight. Tris hydrochloride buffer ( $\mathrm{pH}$ 7.5) containing 1\% RNase A was then added to the plates for $30 \mathrm{~min}$ at $37^{\circ} \mathrm{C}$ in the dark. The cells were subsequently stained with propidium iodide and injected into the flow cytometer for analysis.

2.12. Cell Fractionation. The HL-7702 cells $\left(4 \times 10^{5}\right.$ cells/well) were seeded in 6-well plates and cultured for $24 \mathrm{~h}$. After treatment with graded concentrations of matrine for $48 \mathrm{~h}$, the cells were lysed with ice-cold radio-immunoprecipitation assay (RIPA) buffer for $30 \mathrm{~min}$ and centrifuged at $12,000 \mathrm{rpm}$ for $10 \mathrm{~min}$ at $4^{\circ} \mathrm{C}$. Protein concentration in the cell lysate was determined using the BCA assay kit. The mitochondrial and cytosolic fractions of the lysed cells were also separated using the ProteoExtract ${ }^{\circledR}$ Cytosol/Mitochondria Fractionation kit.

Isolation of nuclear fraction: after treatment with matrine, the cells were washed twice with ice-cold PBS and resuspended in ice-cold hypotonic buffer containing $5 \mu \mathrm{L}$ phosphatase inhibitor, $10 \mu \mathrm{L}$ phenylmethylsulfonyl fluoride (PMSF), and $1 \mu \mathrm{L}$ dithiothreitol (DTT) for $10 \mathrm{~min}$. The mixture was then centrifuged at $3,000 \mathrm{rpm}$ for $5 \mathrm{~min}$ at $4^{\circ} \mathrm{C}$, and the supernatant was discarded. The resultant pellet was washed with cold hypotonic buffer for $30 \mathrm{sec}$ and centrifuged again at $5,000 \mathrm{rpm}$ for $5 \mathrm{~min}$ at $4^{\circ} \mathrm{C}$ to obtain pellet. Ice-cold lysis buffer was added to the pellet for $20 \mathrm{~min}$ to sustain the suspension which was thereafter centrifuged at $15,000 \mathrm{rpm}$ for $10 \mathrm{~min}$ at $4^{\circ} \mathrm{C}$. The resultant supernatant (nuclear fraction) was refrigerated at $-80^{\circ} \mathrm{C}$ prior to use.

2.13. Western Blot. Equal amounts of protein were resolved on sodium dodecyl sulfate-polyacrylamide gels (SDSPAGE) and transferred to polyvinylidene fluoride (PVDF) 


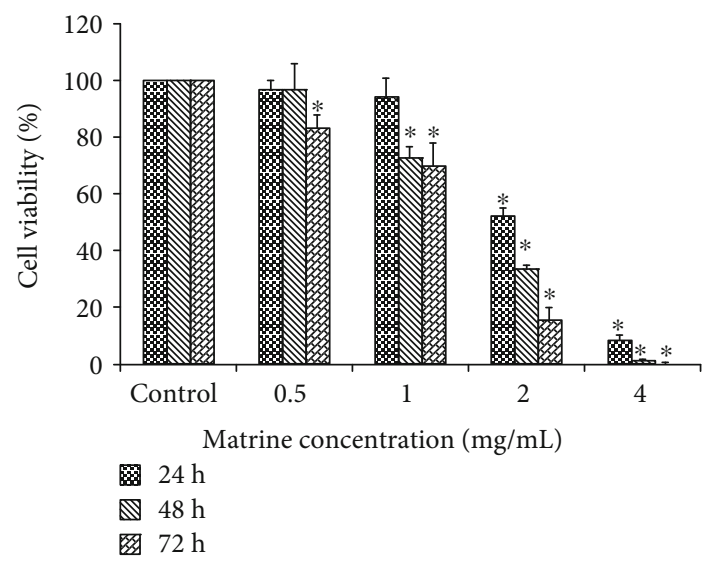

(a)

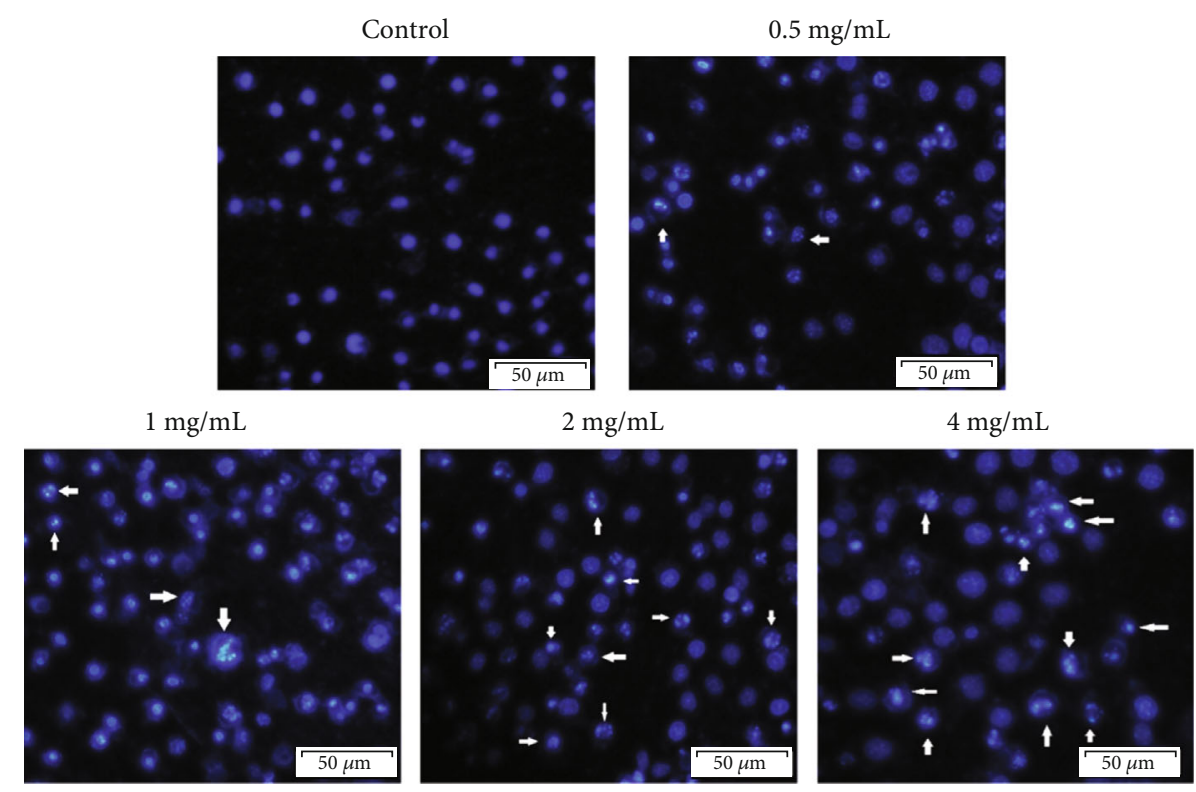

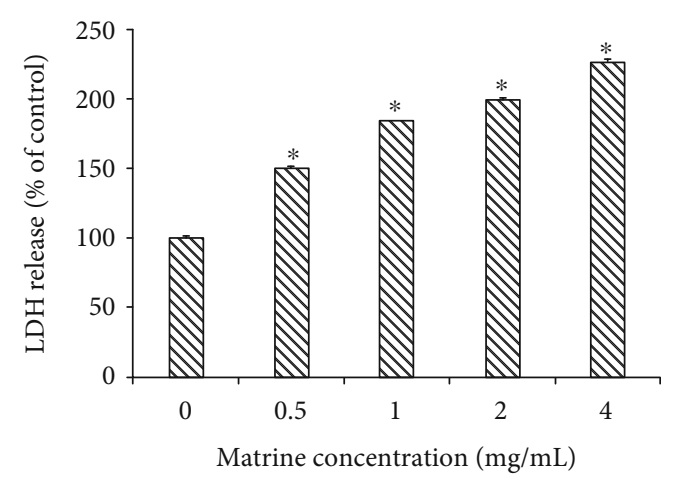

(b)

(c)

FIGURE 2: The cell viability and morphology in HL-7702 cells were detected after treatment with various concentrations of matrine. (a) Cell viability was assessed by the MTT assay. (b) HL-7702 cells were treated with matrine at a series of concentrations $(0-4 \mathrm{mg} / \mathrm{mL})$ for $48 \mathrm{~h}$. The cell cytotoxicity was evaluated by the LDH assay. (c) The morphology changes of the HL-7702 cell nucleus were examined by DAPI staining and observed by fluorescence microscopy. The arrow markers represent the apoptotic cells. The data are presented as the mean \pm S.D. of three independent experiments $\left({ }^{*} p<0.05\right.$ vs. vehicle control).

membrane. After blocking with TBST buffer containing 5\% skim milk for $1 \mathrm{~h}$, the membranes were incubated with primary antibodies overnight at $4^{\circ} \mathrm{C}$, followed by treatment with corresponding secondary antibodies at room temperature for $1 \mathrm{~h}$ [39]. The target proteins were visualized and determined by an intensive ECL detection system.

2.14. Immunoprecipitation. After treatment with matrine, HL-7702 cells were collected and lysed with modified RIPA buffer containing protease inhibitor cocktail. The homogenates were centrifuged at $14,000 \mathrm{rpm}$ for $15 \mathrm{~min}$ at $4^{\circ} \mathrm{C}$. The supernatants were collected and protein concentration was determined by the protein assay kit (Beyotime, Shanghai, China). Whole-cell lysates containing $1 \mathrm{mg}$ of proteins were precleared with protein A-Sepharose beads for $1 \mathrm{~h}$ and incubated with $2 \mu \mathrm{g}$ of anti-Keap 1 antibody for $3 \mathrm{~h}$. Immunopre- cipitated complexes were washed 3-5 times with RIPA buffer and then boiled in SDS sample buffer for $5 \mathrm{~min}$. The supernatant was then electrophoresed by SDS-PAGE for further Nrf2 antibody immunoblotting.

2.15. Statistical Analysis. Data are expressed as mean \pm S.D., and statistical analysis was performed using SPSS (17.0). Groups were compared using the LSD test. Values of $p<0.05$ were considered statistically significant.

\section{Results}

3.1. Matrine Induces Cytotoxicity in HL-7702 Cells. Compared to the control, the results of the MTT assay showed that matrine obviously inhibited the viability of HL-7702 cells in a dose-dependent and time-dependent manner (Figure 2(a)). 

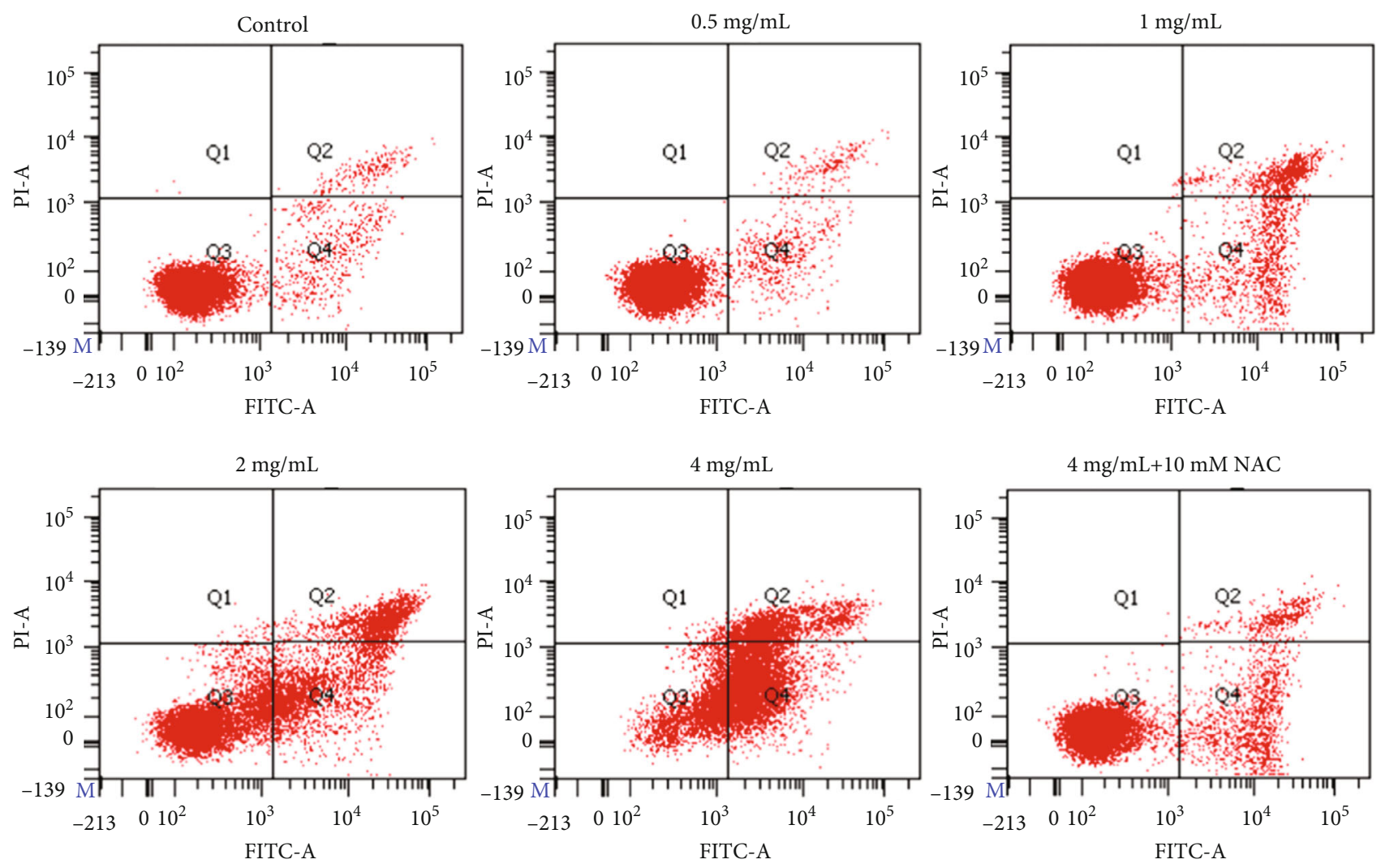

(a)

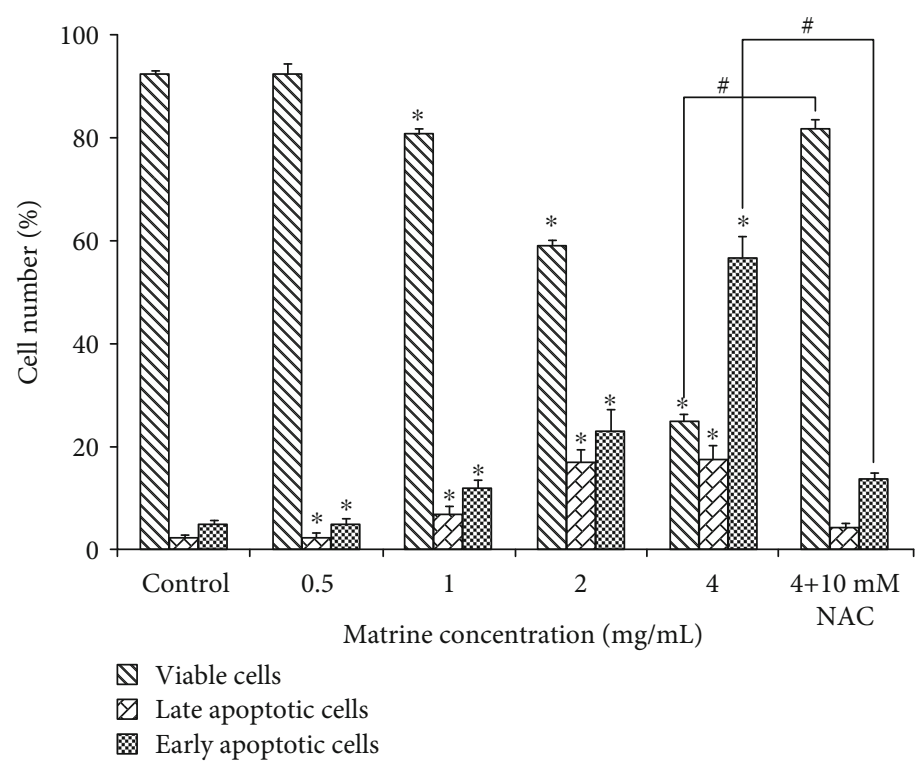

(b)

Figure 3: HL-7702 cells were treated with various concentrations of matrine for $48 \mathrm{~h}$. (a) Apoptosis detection with Annexin V-FITC/PI double staining in different groups by flow cytometry. The Q3 region represents viable cells, while the Q4 region represents early apoptotic cells. The Q2 region represents late apoptotic cells, while the Q1 region represents necrotic cells or mechanical damaged cells. (b) Column bar graph of mean cell florescence for viable, early apoptotic, and late apoptotic cells. The data are presented as the mean \pm S.D. of three independent experiments $\left({ }^{*} p<0.05\right.$ vs. vehicle control, ${ }^{\#} p<0.05$ vs. matrine $4 \mathrm{mg} / \mathrm{mL}$-treated group).

The $\mathrm{IC}_{50}$ value of matrine for $48 \mathrm{~h}$ was $1.446 \pm 0.10 \mathrm{mg} / \mathrm{mL}$ for HL-7702 cells. When the cell membrane is damaged, $\mathrm{LDH}$ is released from the cytoplasm into the extracellular medium, and its release represents disruption of cell membrane integrity. In this study, matrine treatment led to the leakage of LDH observed on HL-7702 cells in a concentration-dependent manner (Figure 2(b)). Next, in order to validate whether the inhibitory effect of matrine 

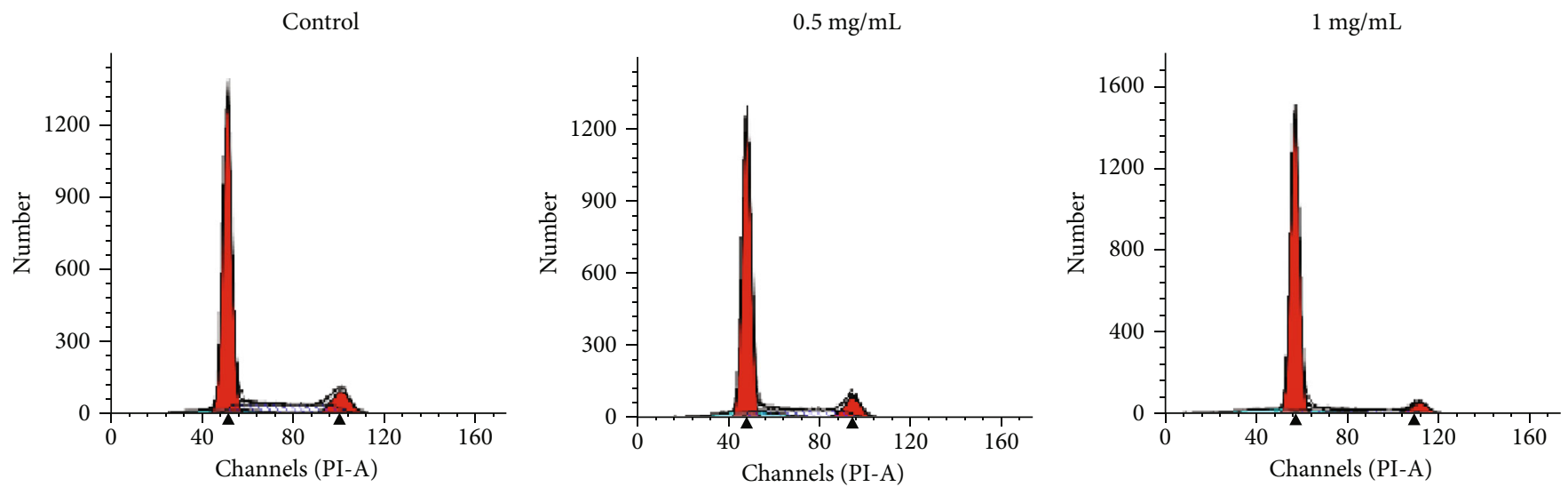

$2 \mathrm{mg} / \mathrm{mL}$
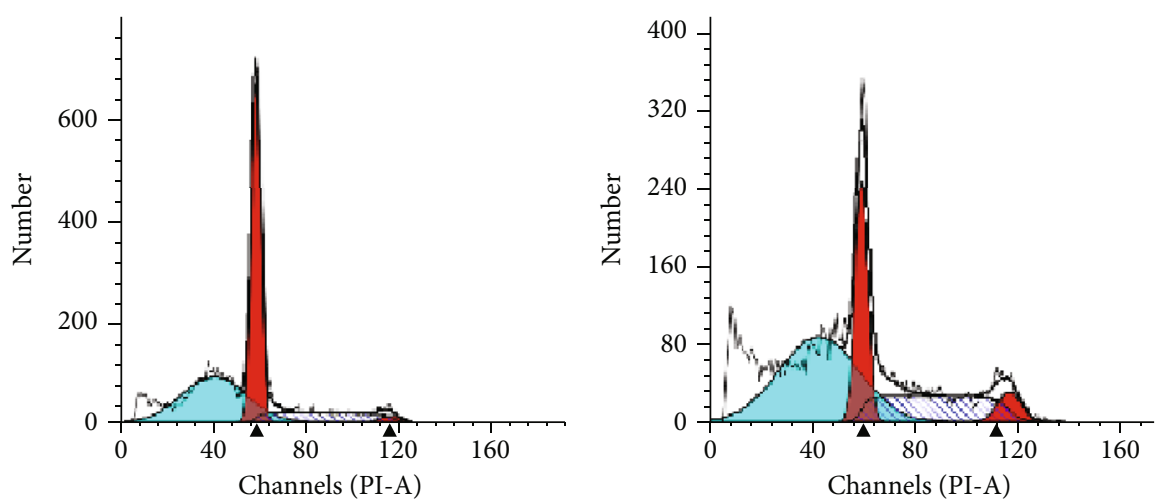
$\square$ Apoptosis
$\square$ Dip G2
$\square$ Dip G1
图 Dip S

(a)

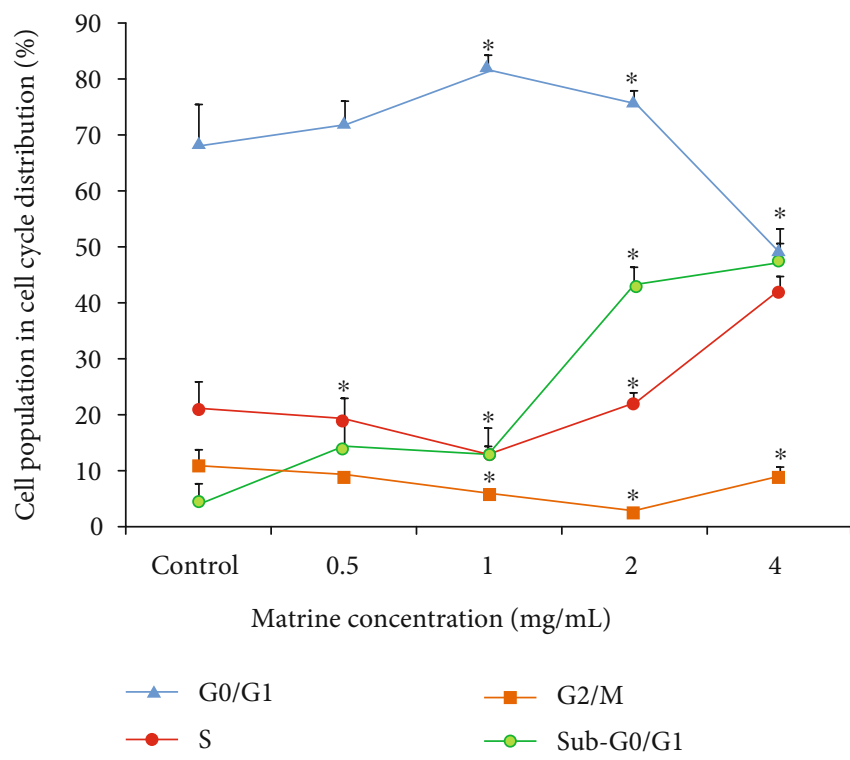

(b)

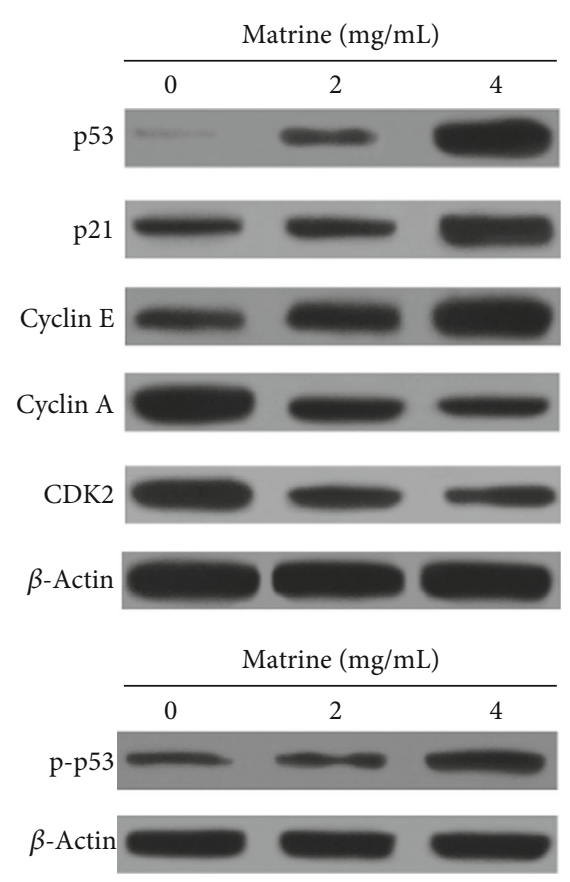

(c)

Figure 4: Continued. 


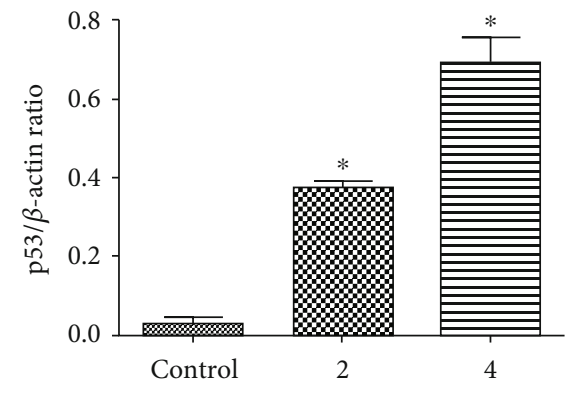

Matrine concentration $(\mathrm{mg} / \mathrm{mL})$

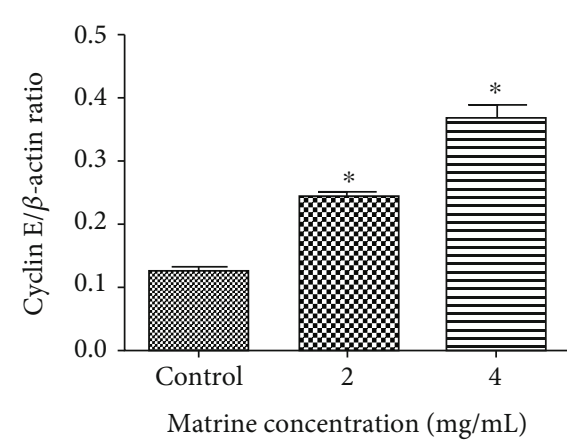

Matrine concentration (mg/mL)
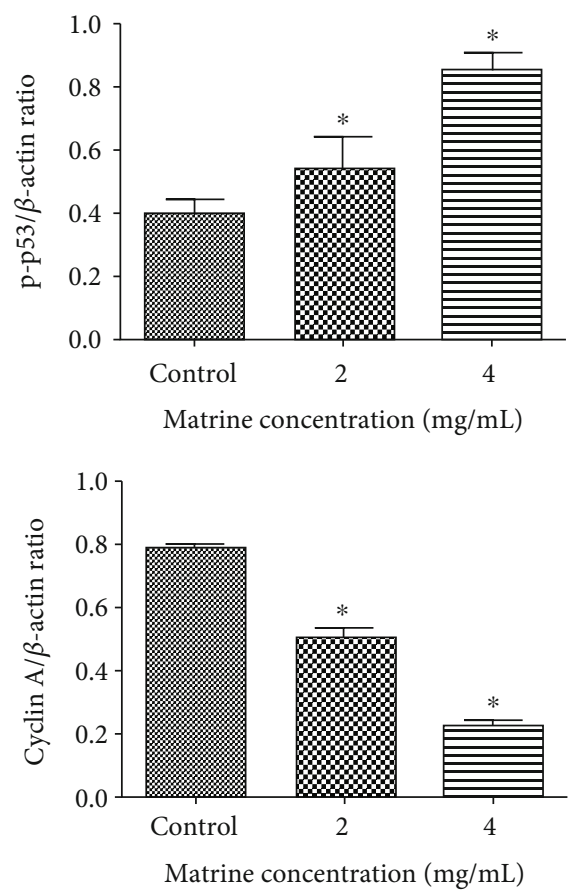

(d)
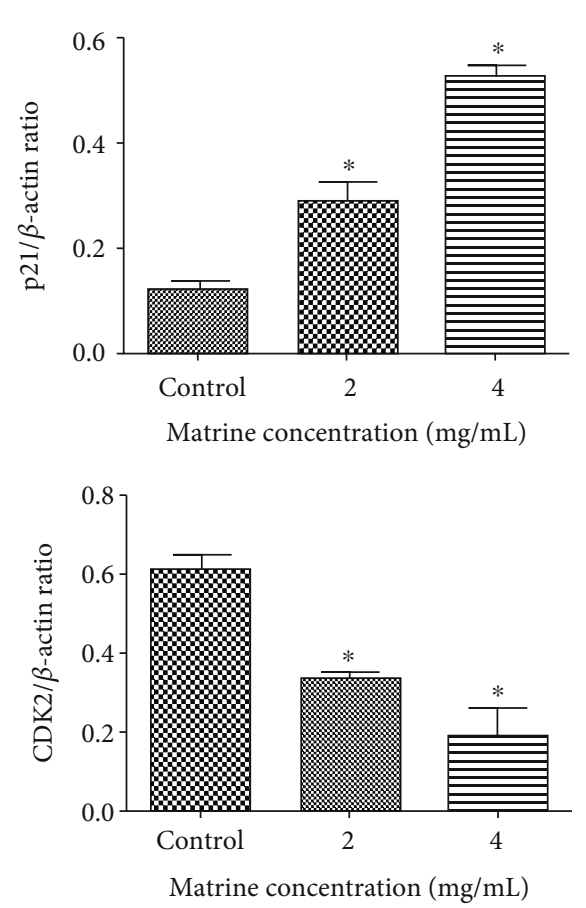

FIGURE 4: Effect of matrine on the distribution of HL-7702 cells among phases of the cell cycle. (a) Matrine induced cell cycle arrest at the S phases. (b) Each phase of the cell cycle was shown in a polyline diagram. (c) The expression levels of the correlative proteins were measured by western blot. $\beta$-Actin was used as a loading control. (d) Densitometric analysis was used to quantify these protein-related bands and statistically analyze. The data and each image are expressed as the mean \pm S.D. of three independent experiments $\left({ }^{*} p<0.05\right.$ vs. vehicle control).

on cell growth is related to apoptosis, the morphological changes of the HL-7702 cell incubated with matrine (0$4 \mathrm{mg} / \mathrm{mL}$ ) were evaluated by staining with DAPI fluorescent dye. As shown in Figure 2(c), treatment with matrine significantly and concentration-dependently promoted apoptosis in HL-7702 cells $(p<0.05)$. Apoptosis was evidenced by chromatin condensation, nuclear fragmentation, and apoptotic body formation.

3.2. Matrine Induces Apoptosis in HL-7702 Cells. As shown in Figures 3(a) and 3(b), the percentage of viable cells was significantly lower after incubation with matrine for $48 \mathrm{~h}$. Moreover, the percentage of early and late apoptotic cells was clearly increased in a dose-dependent manner from $5.13 \% \pm 0.70$ to $56.80 \% \pm 4.11$ and $2.37 \% \pm 0.50$ to 17.57 $\% \pm 2.89$, respectively. Meanwhile, we also detected the presence of a subpopulation of G0/G1 cells corresponding to apoptotic DNA fragmentation by cell cycle analysis (Figures 4(a) and 4(b)). In addition, matrine-induced apoptosis can be partially blocked by the ROS inhibitor NAC $(10 \mathrm{mM})$. These results demonstrate that apoptosis is one of the ways through which matrine induces HL-7702 cell death.

\subsection{Activation of Oxidative Stress and Mitochondrial Injury by Matrine in HL-7702 Cells}

3.3.1. Matrine-Induced Oxidative Stress in HL-7702 Cells. The generation of ROS plays an important role in oxidative stress and apoptosis [40]. Compared with the control group, the intracellular ROS and lipid peroxidation MDA level increased in a dose-dependent manner after the cells were exposed to matrine for $48 \mathrm{~h}$ (Figures 5(a) and 5(b)). After treatment with different doses of matrine, the antioxidant SOD and GSH levels were markedly reduced (Figure 5(b)). These results indicated that matrine could induce oxidative stress in HL-7702 cells.

3.3.2. Effect of Matrine on Mitochondrial Dysfunction in HL-7702 Cells. After confirming the effect of matrine on the apoptosis of HL-7702 cells, we then investigated whether mitochondrial dysfunction mediates matrineinduced apoptosis. Previous studies have shown that the loss of mitochondrial membrane potential (MMP) can increase mitochondrial outer membrane permeability, leading to mitochondrial dysfunction and activation of cytochrome $c$ release $[41,42]$. Compared with the control group, treatment of HL-7702 cells with matrine induced a significant loss of MMP in a dose-dependent manner (Figures 6(a) and 6(b)). The mitochondria-dependent apoptosis pathways involves signaling of mitochondrialassociated apoptotic proteins, including Bax and Bcl-2. Treatment of HL-7702 cells with matrine increased Bax and decreased Bcl-2 expression in a concentrationdependent manner, which increased the ratio of proapoptotic/antiapoptotic proteins (Figure 7). Moreover, our study demonstrated that matrine significantly increased the release of cytochrome $c$ from the mitochondria into the cytoplasm (Figures 6(c) and 6(d)). Taken together, 

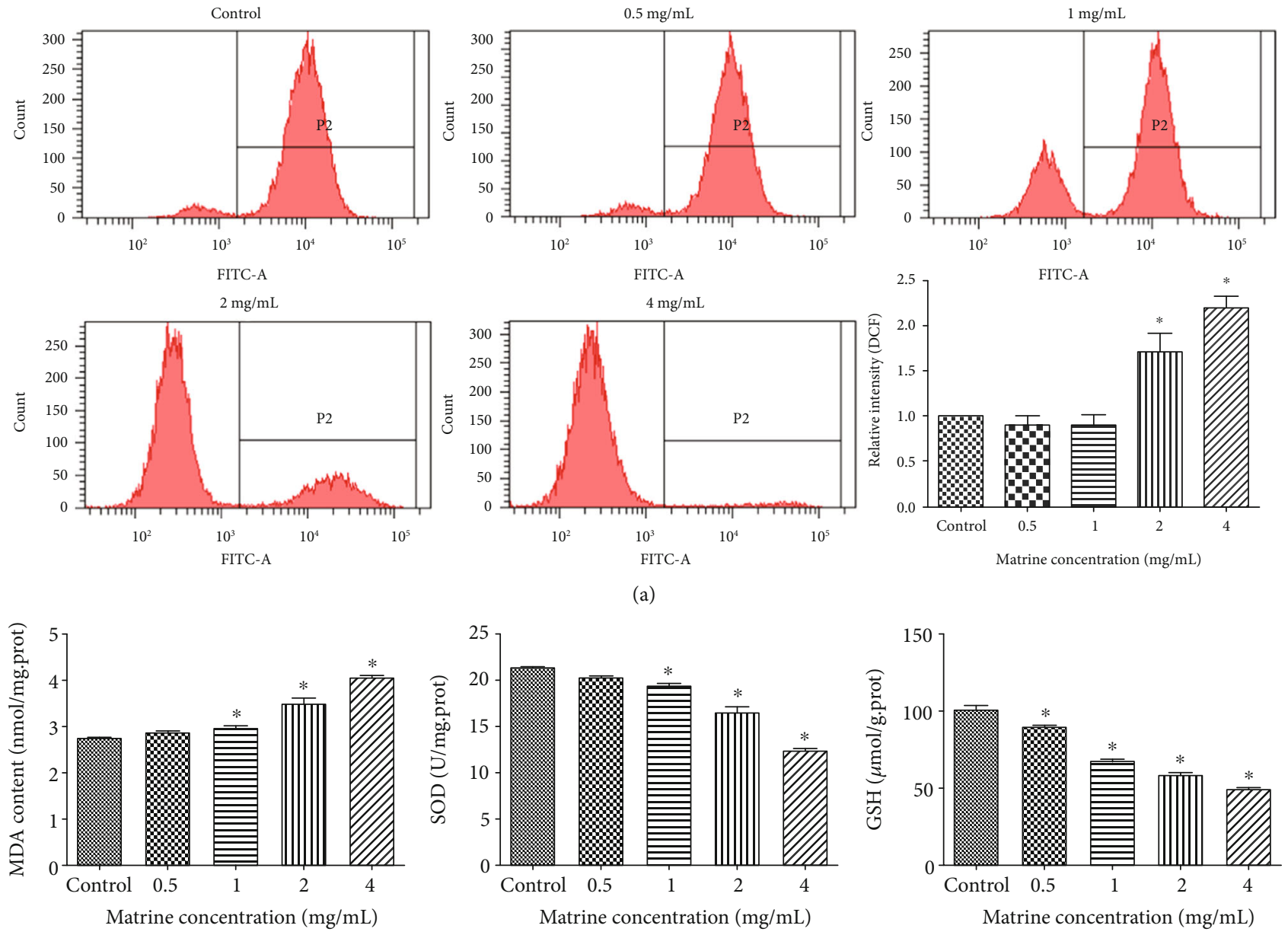

(b)

FIgURE 5: Matrine-induced oxidative stress in HL-7702 cells. Cells were incubated with matrine (0-4 mg/mL) for $48 \mathrm{~h}$. (a) ROS detection with DCFH-DA dye in different groups by flow cytometry. (b) Lipid peroxidation MDA content and antioxidant SOD or GSH level in cells were measured. The data are presented as the mean \pm S.D. of three independent experiments $\left({ }^{*} p<0.05\right.$ vs. vehicle control $)$.

these results indicate that mitochondrial dysfunction is involved in matrine-induced apoptosis of HL-7702 cells.

3.4. Matrine Induces Cell Cycle Arrest in S Phase of HL-7702 Cells. To confirm the effects of matrine on cell cycle, the cell cycle distribution of matrine-treated cells was analyzed by flow cytometry. As shown in Figures 4(a) and 4(b), exposure of HL-7702 cells to matrine for $48 \mathrm{~h}$ resulted in an obvious increase in $S$ phase cells and a corresponding decrease in G0/G1 and G2/M phase cells when compared with untreated cells. Furthermore, treatment with 2 and $4 \mathrm{mg} / \mathrm{mL}$ matrine for $48 \mathrm{~h}$ markedly upregulated the expression level of $\mathrm{p} 53, \mathrm{p}-\mathrm{p} 53$, and $\mathrm{p} 21$ protein in a dose-dependent manner. Cyclin-dependent kinases (CDKs) complexed with corresponding cyclins were involved in cell cycle progression [43]. As shown in Figures 4(c) and 4(d), matrine treatment for $48 \mathrm{~h}$ led to significant and concentration-dependent upregulations of the expression of cyclin $\mathrm{E}$ and downregulation of CDK2 and cyclin A expressions. Together, these results indicate that matrine induces $\mathrm{S}$ phase cell cycle arrest in HL-7702 cells.
3.5. Matrine Regulates the Expression of Apoptosis-Related Proteins in HL-7702 Cells. As shown in Figure 7, matrine treatment significantly and concentration-dependently increased the expressions of Bax, cleaved caspase-3, caspase- 8 , and caspase- 9 but significantly reduced the expression of Bcl-2. It also significantly promoted the cleavage of PARP. Furthermore, Figure 7 shows that matrine significantly upregulated the expression of Fas, a typical death receptor. Collectively, these results indicate that activation of death receptors and mitochondrial-dependent apoptotic pathways is involved in matrine-induced apoptosis.

\subsection{Matrine Inhibits Nrf2 Pathway Activation Associated} with Oxidative Stress. As shown in Figure 8, matrine significantly and concentration-dependently upregulated Keap1 expression and downregulated the expressions of cellular total Nrf2 and the nuclear Nrf2. It also significantly inhibited the expressions of downstream oxidoreductase (HO-1 and NQO-1) expression and promoted the formation of Keap1/Nrf2 protein complex. These results indicate that the oxidative-antioxidant balance of HL-7702 cells is 

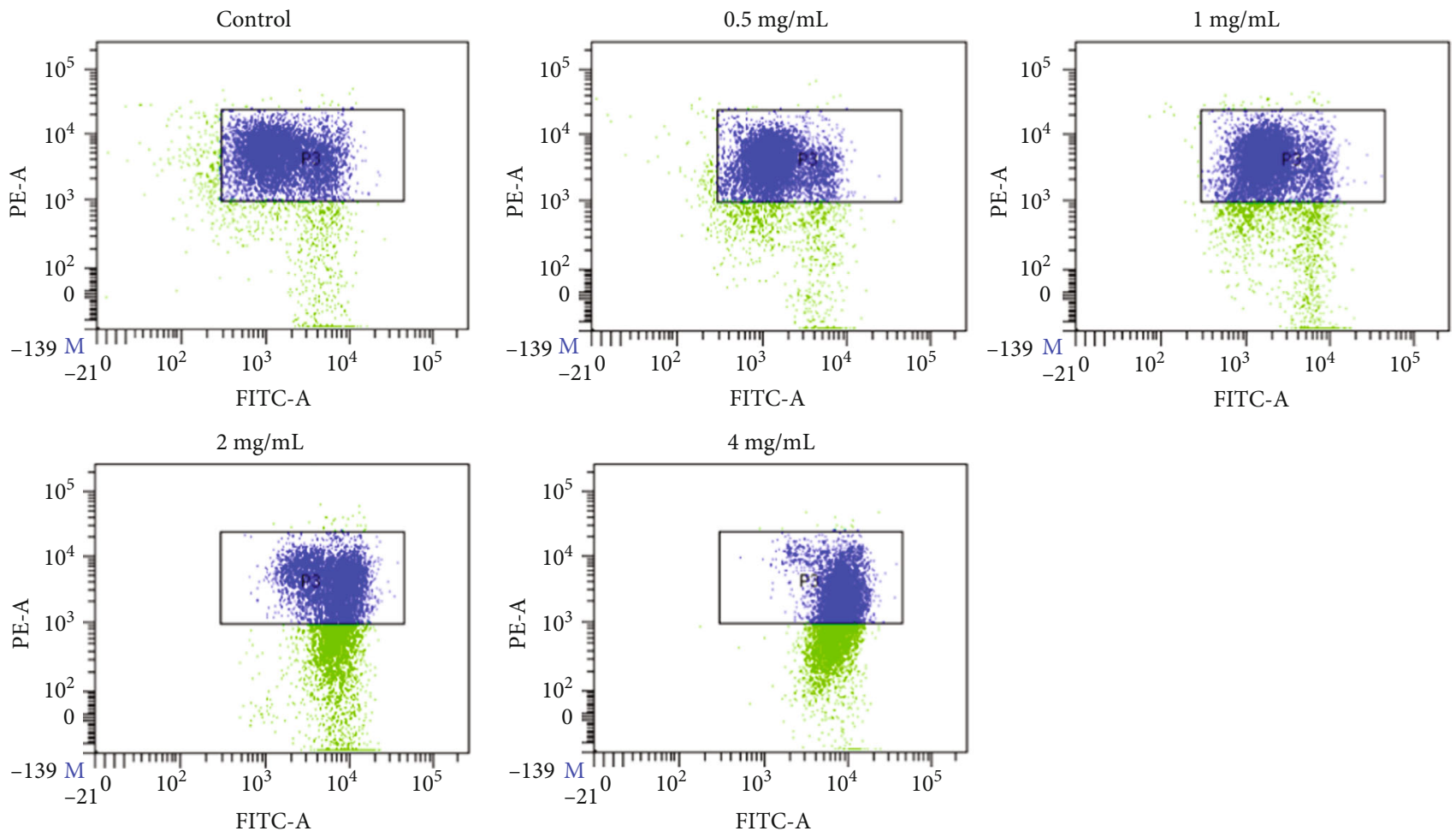

(a)

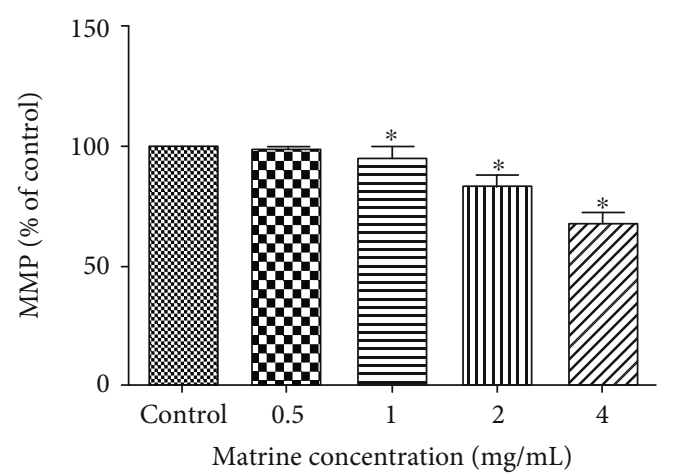

(b)

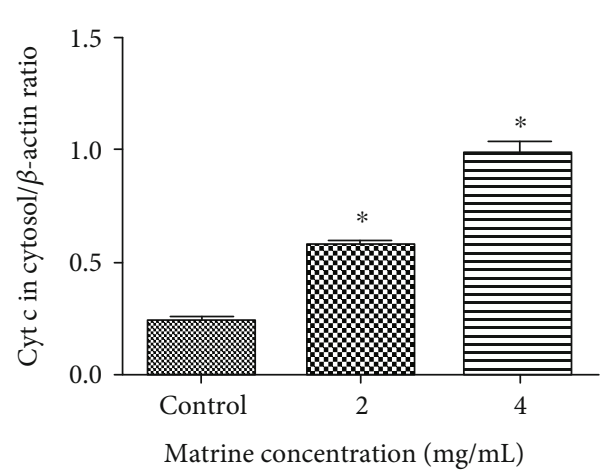

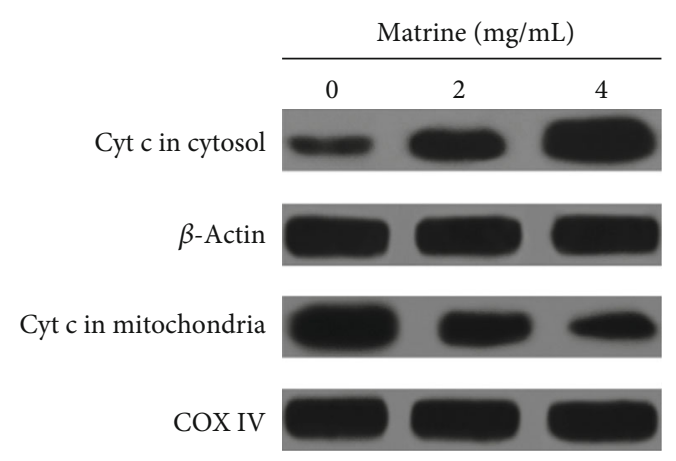

(c)

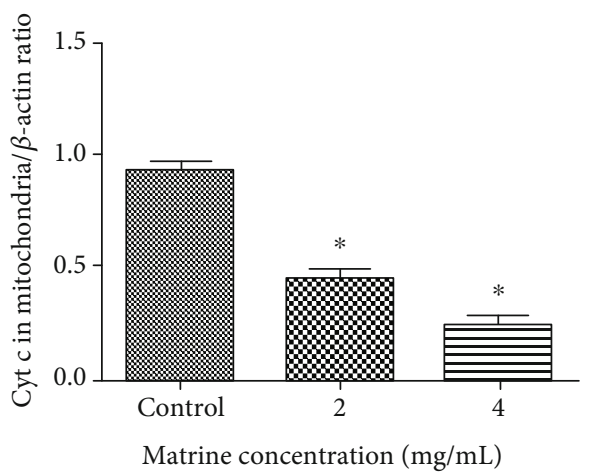

(d)

FIGURE 6: Effect of matrine on MMP in HL-7702 cells. (a) MMP detection with JC-1 staining in different groups by flow cytometry. (b) Column bar graph of mean cell florescent for JC-1. (c) The release of cytochrome $c$ in the mitochondria and cytosol was examined by western blotting. $\beta$-Actin and COX IV were analyzed as the internal control for the cytosolic and mitochondrial fractions, respectively. (d) Densitometric analysis was used to quantify these protein-related bands and statistically analyze. The data and each image are expressed as the mean \pm S.D. of three independent experiments $\left({ }^{*} p<0.05\right.$ vs. vehicle control). 

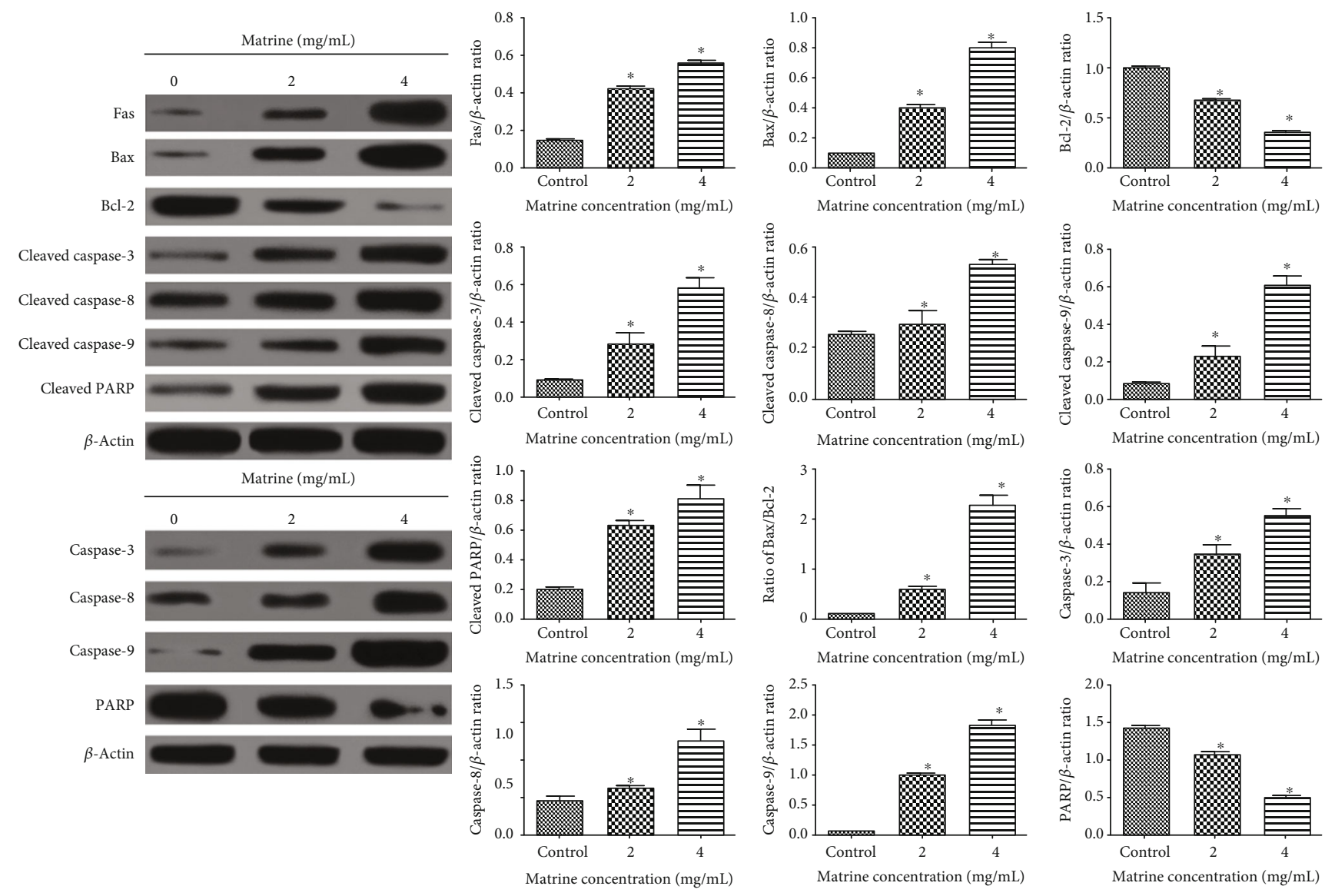

FIGURE 7: Effect of matrine on the expressions of apoptosis-related proteins as measured using western blotting. Densitometric analysis was used to quantify these protein-related bands and statistically analyze. The data and each image are expressed as the mean \pm S.D. of three independent experiments $\left({ }^{*} \mathrm{p}<0.05\right.$ vs. vehicle control).

disrupted, leading to inhibition of the Nrf2 pathway, which corresponds to our previous ROS assay results.

\section{Discussion}

Matrine is an alkaloid isolated from Sophora flavescens, a plant used in TCM for the treatment of several diseases. It possesses a wide range of pharmacological properties. However, its use in clinical practice is greatly limited due to its speculated toxic effects. Despite the wide speculation about its potential adverse effect, the underlying mechanism has not been fully elucidated.

The results obtained from MTT and LDH assays showed that matrine had a significant cytotoxic effect on HL-7702 cells in a concentration- and time-dependent manner, indicating that it may have hepatotoxicity. Studies have shown that apoptosis is involved in the pathogenesis of hepatocyte injury and liver diseases [44, 45]. Therefore, to assess the association between matrine and apoptosis, the levels of different apoptotic markers in HL-7702 cells after exposure to graded concentrations of matrine were determined. The results showed that matrine induced apoptosis in HL-7702 cells in a concentrationdependent manner.
In a death receptor-mediated apoptotic pathway, the activation of downstream caspase- 8 in turn activates Fas ligand (FasL) receptor [46]. Mitochondrial dysfunction which is characterized by increased mitochondrial membrane permeability is usually accompanied by the release of several mitochondrial proteins into the cytosol [47]. Cytochrome $c$ is a proapoptotic protein, and its release activates downstream caspase-dependent apoptosis [48]. It has been reported that $\mathrm{Bcl}-2$ prevents the release of cytochrome $c$ into the cytosol, and that together with its homologs, it maintains the integrity of mitochondrial membrane [49].

In this study, matrine significantly upregulated the expressions of Fas, cleaved caspase-3, caspase-8, caspase-9, and PARP and the Bax/Bcl-2 ratio. Meanwhile, matrine significantly increased the release of cytochrome $c$. These results suggest that matrine may induce apoptosis in HL-7702 cells via the Fas death receptor-mediated and caspase-dependent mitochondrial apoptotic pathways. Previous studies have shown that matrine activates the mitochondrial apoptotic pathway in esophageal cancer cells [50]. Thus, results obtained in this study suggest that mitochondrial-initiated ROS activation may be also involved in matrine-induced cell death of HL-7702 cells isolated from normal human liver cell and underlie cellular hepatotoxicity. 


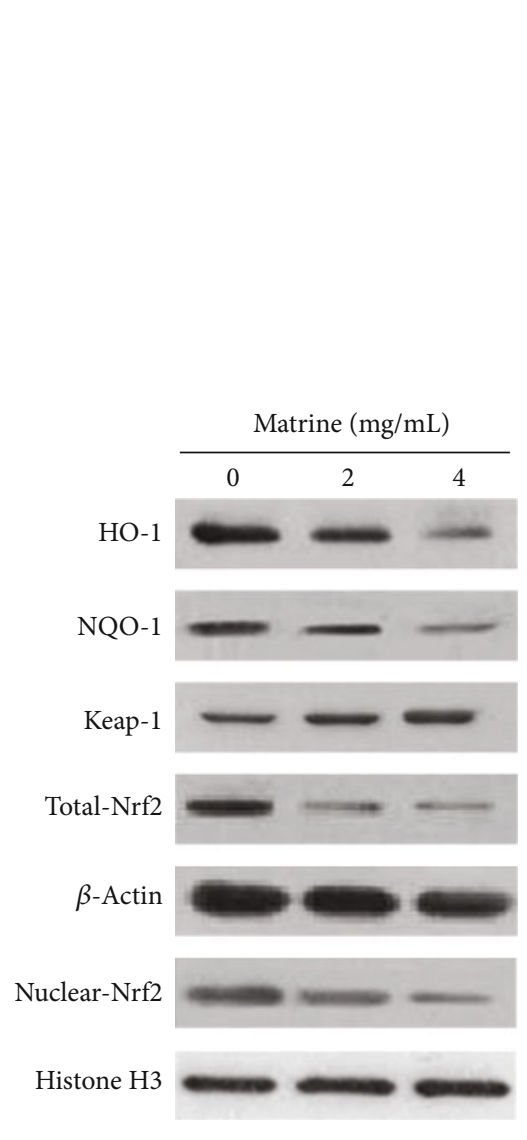

(a)

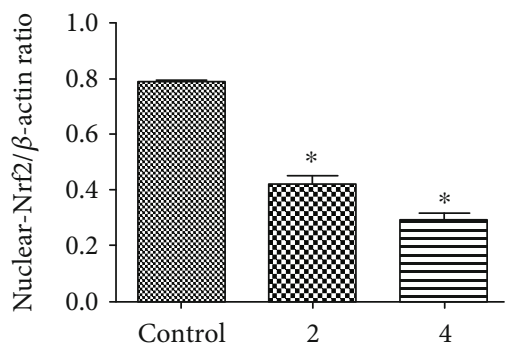

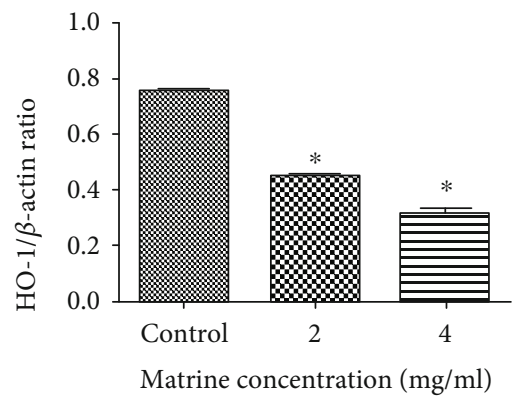

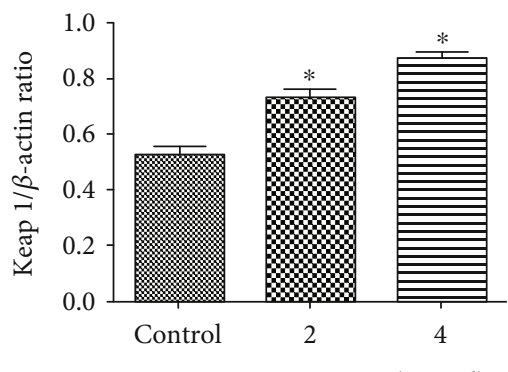

Matrine concentration (mg/ml)
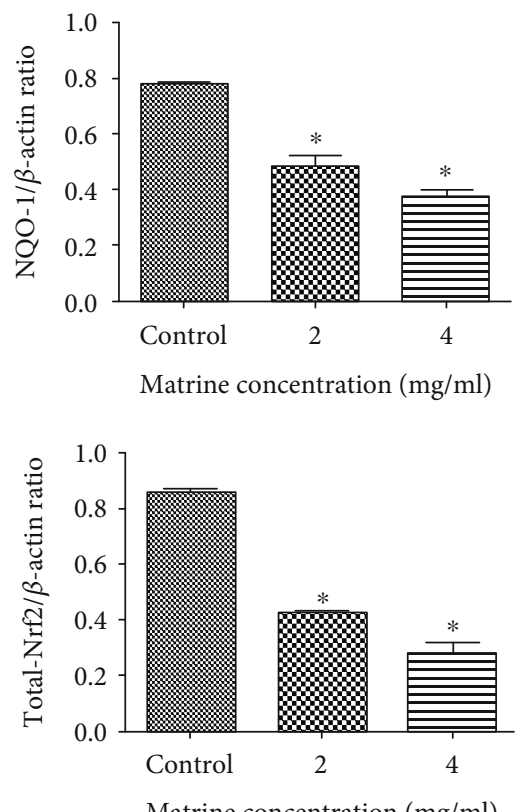

(b)

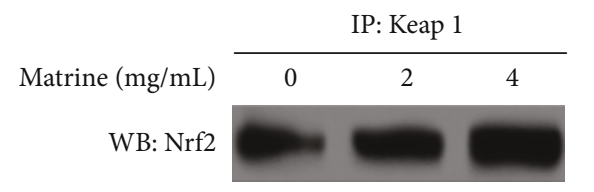

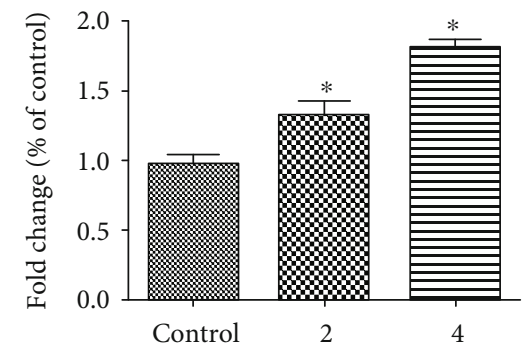

(c)

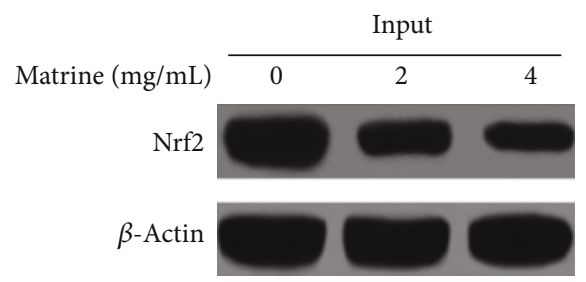

(d)

Figure 8: Effects of matrine on Nrf2 pathway. (a) The effects of matrine on the expression levels of Nrf2, Keap1, HO-1, and NQO-1 were measured by western blot after treatment with various concentrations of matrine for $48 \mathrm{~h}$. (b) Densitometric analysis was used to quantify these protein-related bands (Nrf2, Keap1, HO-1, and NQO-1) and statistically analyze. (c) Effect of matrine on the formation of Keap1/Nrf2 complex. (d) Western blot analysis of Nrf2. HL-7702 cells were treated with matrine $(0-4 \mathrm{mg} / \mathrm{mL})$ for $48 \mathrm{~h}$. The whole-cell lysates were analyzed by western blot analysis with the indicated antibodies. The data and each image are expressed as the mean \pm S.D. of three independent experiments $\left({ }^{*} p<0.05\right.$ vs. vehicle control).

Oxidative stress plays an important role in the pathogenesis of diseases [51]. The generation of intracellular ROS is closely associated with cell apoptosis $[52,53]$. ROS-induced oxidative damage regulates the $\mathrm{Bax} / \mathrm{Bcl}-2$ balance, stimulates mitochondrial membrane depolarization, and releases cytochrome $c$ from mitochondria into the cytosol $[54,55]$. In this study, matrine treatment significantly increased intracellular ROS level, Bax/Bcl-2 ratio, and cytochrome $c$ release and 


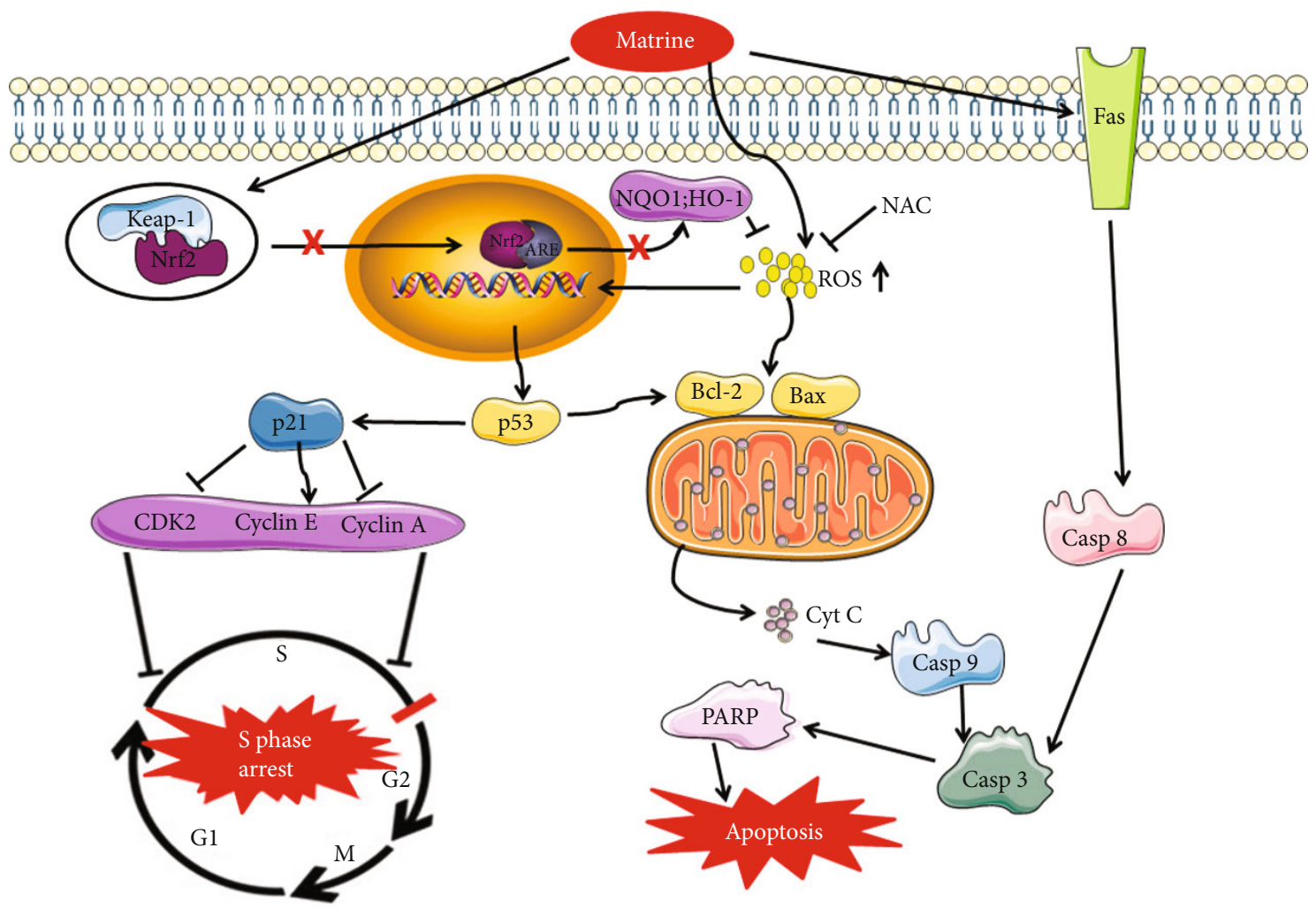

Figure 9: The schematic mechanism of matrine signaling pathway that inhibits cell growth and leads to cell death in HL-7702 cells.

significantly reduced MMP. In addition, the level of MDA was significantly increased in matrine-treated HL-7702 cells, an indication that the cells were damaged due to lipid peroxidation. Intracellular SOD and GSH are natural antioxidants that scavenge free radicals such as ROS. The results of this study showed that matrine significantly reduced the antioxidant capacity of HL-7702 cells by decreasing the activity of SOD and reducing GSH levels. In addition, pretreatment with NAC effectively blocked matrine-induced apoptosis. It is likely that matrine induced oxidative damage in HL-7702 cells via the generation of ROS which acted on upstream signaling molecules to trigger cell apoptosis.

It is generally believed that the overproduction of ROS is key in the activation of mitochondria-induced caspase cascade and that the Nrf2 pathway plays an important role in the defense mechanism of cells against oxidative damage [56]. In this study, treatment of HL-7702 cells with matrine significantly downregulated the expression of cellular total Nrf2 and the nuclear Nrf2. However, the formation of Keap1/Nrf2 protein complex was significantly increased by matrine treatment. These results suggest that matrine may have suppressed the induction of antioxidant defenses in HL-7702 cells. It is likely that matrine reduced the antioxidant defense mechanism of HL-7702 cells by targeting the formation of Keap1/Nrf2 complex. It is also possible that matrine may have inhibited nuclear translocation of Nrf2, thereby suppressing downstream antioxidant protein expression. It is likely that matrine-induced oxidative damage may be due partly to the inhibition of its Nrf2-mediated antioxidant activities.
There is an association between oxidative stress and DNA damage [57]. Oxidative damage to DNA due to overproduction of ROS results in rapid activation of p53 and its accumulation within the nucleus $[58,59]$. The p21 protein is an inhibitor of cyclin-dependent kinases (CDKs) [60, 61]. Cell cycle is controlled by cyclins, CDKs, and cyclin-dependent kinase inhibitors (CDKIs). Cyclin A is required for both the initiation and elongation of DNA in the late G1 and S phases, while p21 inhibits cyclin A, thereby blocking cell cycle progression from $S$ to $\mathrm{G} 2 / \mathrm{M}$ phase $[62,63]$. In this study, the expressions of cyclin A and CDK2 were significantly downregulated, while the expressions of p53, p-p53, and p21 proteins were significantly upregulated. These results indicate that matrine may arrest cell cycle in the $S$ phase via activation of $\mathrm{p} 53$ expression. It has been reported that p53 triggers apoptosis via the regulation of expression of apoptosis-related proteins such as Bcl-2 and Bax [64]. The results of this study indicate that overproduction of ROS may cause oxidative damage to DNA, which indirectly leads to $S$ phase cell cycle arrest and activation of mitochondrial-dependent apoptosis pathway.

\section{Conclusions}

The results obtained in this study show that the hepatotoxic effect of matrine is exerted via inhibition of $\mathrm{Nrf} 2$ pathway, activation of ROS-mediated mitochondrial apoptosis pathway, and cell cycle arrest at S phase (Figure 9). Pretreatment with NAC partially reverses matrine-induced hepatotoxicity. 


\section{Data Availability}

Parts of data used to support the findings of this study are included within the article. In addition, the data used to support the findings of this study are available from the corresponding author upon request.

\section{Conflicts of Interest}

The authors declare no conflict of interests.

\section{Authors' Contributions}

Longtai You, Xiaoxv Dong, Xingbin Yin, and Jian Ni designed the research. Yuanyuan Du, Gongsen Chen, Yi Liu, and $\mathrm{Na}$ Sai performed the experiments. Longtai You and Chunjing Yang conducted the data analyses. Longtai You wrote the paper. All authors have reviewed and approved the final version of the manuscript.

\section{Acknowledgments}

This work was financially supported by the Training Programme of the Beijing Municipal Excellent Talents Foundation (No. 2017000020124G295).

\section{References}

[1] C. Chang, S. P. Liu, C. H. Fang et al., "Effects of matrine on the proliferation of HT29 human colon cancer cells and its antitumor mechanism," Oncology Letters, vol. 6, no. 3, pp. 699-704, 2013.

[2] Q. An, C. Han, Y. Zhou et al., "Matrine induces cell cycle arrest and apoptosis with recovery of the expression of miR-126 in the A549 non-small cell lung cancer cell line," Molecular Medicine Reports, vol. 14, no. 5, pp. 4042-4048, 2016.

[3] X. Gong, Y. Gao, G. Guo et al., "Effect of matrine on primary human hepatocytes in vitro," Cytotechnology, vol. 67, no. 2, pp. 255-265, 2015.

[4] N. Sun, Z. W. Wang, C. H. Wu et al., "Antiviral activity and underlying molecular mechanisms of matrine against porcine reproductive and respiratory syndrome virus in vitro," Research in Veterinary Science, vol. 96, no. 2, pp. 323-327, 2014.

[5] J. F. Zhang and F. Han, "Progress on clinical application of matrine preparation," Western Journal of Traditional Chinese Medicine, vol. 25, no. 5, pp. 107-110, 2012.

[6] L. Wang, C. Gao, S. Yao, and B. Xie, "Blocking autophagic flux enhances matrine-induced apoptosis in human hepatoma cells," International Journal of Molecular Sciences, vol. 14, no. 12, pp. 23212-23230, 2013.

[7] L. Duan, L. J. Deng, D. B. Wang, S. Ma, C. Li, and D. Zhao, "Treatment mechanism of matrine in combination with irinotecan for colon cancer," Oncology Letters, vol. 14, no. 2, pp. 2300-2304, 2017.

[8] L. Ma, Z. Zhu, L. Jiang et al., "Matrine suppresses cell growth of human chronic myeloid leukemia cells via its inhibition of the interleukin-6/Janus activated kinase/signal transducer and activator of transcription 3 signaling cohort," Leukemia \& Lymphoma, vol. 56, no. 10, pp. 2923-2930, 2015.
[9] H. Zhou, M. Xu, Y. Gao et al., "Matrine induces caspaseindependent program cell death in hepatocellular carcinoma through bid-mediated nuclear translocation of apoptosis inducing factor," Molecular Cancer, vol. 13, no. 1, p. 59, 2014.

[10] H. Li, X. Li, M. Bai, Y. Suo, G. Zhang, and X. Cao, "Matrine inhibited proliferation and increased apoptosis in human breast cancer MCF-7 cells via upregulation of Bax and downregulation of Bcl-2," International Journal of Clinical and Experimental Pathology, vol. 8, no. 11, pp. 14793-14799, 2015.

[11] Z. G. Lu, M. H. Li, J. S. Wang, D.-D. Wei, Q.-W. Liu, and L.-Y. Kong, "Developmental toxicity and neurotoxicity of two matrine-type alkaloids, matrine and sophocarpine, in zebrafish (Danio rerio) embryos/larvae," Reproductive Toxicology, vol. 47, pp. 33-41, 2014.

[12] Q. Guo, G. Chen, Q. Zhou, and R. Jin, “Comparison of hepatotoxicity and toxic mechanisms of matrine and oxymatrine using in vivo and in vitro models," Chinese Journal of Comparative Medicine, vol. 28, no. 1, pp. 44-50, 2018.

[13] Q. Guo and R. M. Jin, "Comparison of liver toxicity of matrine and oxymatrine in mice," Chinese Journal of Pharmacology and Toxicology, vol. 30, no. 7, pp. 736-740, 2016.

[14] T. Y. Liu, Y. Song, H. Chen, S. H. Pan, and X. Y. Sun, "Matrine inhibits proliferation and induces apoptosis of pancreatic cancer cells in vitro and in vivo," Biological and Pharmaceutical Bulletin, vol. 33, no. 10, pp. 1740-1745, 2010.

[15] D. Pessayre, A. Mansouri, D. Haouzi, and B. Fromenty, "Hepatotoxicity due to mitochondrial dysfunction," Cell Biology and Toxicology, vol. 15, no. 6, pp. 367-373, 1999.

[16] J. Shi, J. Zhou, H. Ma et al., "An in vitro metabolomics approach to identify hepatotoxicity biomarkers in human L02 liver cells treated with pekinenal, a natural compound," Analytical and Bioanalytical Chemistry, vol. 408, no. 5, pp. 1413-1424, 2016.

[17] E. S. Park, J. C. Kang, D. H. Kang et al., "5-AIQ inhibits H2O2induced apoptosis through reactive oxygen species scavenging and Akt/GSK-3 $\beta$ signaling pathway in H9c2 cardiomyocytes," Toxicology and Applied Pharmacology, vol. 268, no. 1, pp. 90-98, 2013.

[18] B. Qu, Q. T. Li, K. P. Wong, T. M. C. Tan, and B. Halliwell, "Mechanism of clofibrate hepatotoxicity: mitochondrial damage and oxidative stress in hepatocytes," Free Radical Biology and Medicine, vol. 31, no. 5, pp. 659-669, 2001.

[19] B. Herpers, S. Wink, L. Fredriksson et al., "Activation of the Nrf2 response by intrinsic hepatotoxic drugs correlates with suppression of NF- $\kappa \mathrm{B}$ activation and sensitizes toward TNF $\alpha$-induced cytotoxicity," Archives of Toxicology, vol. 90, no. 5, pp. 1163-1179, 2016.

[20] T. Nguyen, P. Nioi, and C. B. Pickett, “The Nrf2-antioxidant response element signaling pathway and its activation by oxidative stress," Journal of Biological Chemistry, vol. 284, no. 20, pp. 13291-13295, 2009.

[21] T. Nguyen, C. S. Yang, and C. B. Pickett, "The pathways and molecular mechanisms regulating $\mathrm{Nrf} 2$ activation in response to chemical stress," Free Radical Biology and Medicine, vol. 37, no. 4, pp. 433-441, 2004.

[22] B. H. Zhou, H. W. Wang, F. Q. Xue et al., "Effects of diclazuril on apoptosis and mitochondrial transmembrane potential in second-generation merozoites of Eimeria tenella," Veterinary Parasitology, vol. 168, no. 3-4, pp. 217-222, 2010.

[23] L. T. You, X. X. Dong, X. B. Yin et al., "Rhein induces cell death in HepaRG cells through cell cycle arrest and apoptotic 
pathway," International Journal of Molecular Sciences, vol. 19, no. 4, p. 1060, 2018.

[24] X. Wen, Z. Q. Lin, B. Liu, and Y. Q. Wei, “Caspase-mediated programmed cell death pathways as potential therapeutic targets in cancer," Cell Proliferation, vol. 45, no. 3, pp. 217-224, 2012.

[25] W. P. Tsang and T. T. Kwok, "Let-7a microRNA suppresses therapeutics-induced cancer cell death by targeting caspase3," Apoptosis, vol. 13, no. 10, pp. 1215-1222, 2008.

[26] Q. Huang, F. Li, and X. J. Liu, "Caspase 3-mediated stimulation of tumor cell repopulation during cancer radiotherapy," Nature Medicine, vol. 17, no. 7, pp. 860-866, 2011.

[27] B. Liu, B. Yuan, L. Zhang, W. Mu, and C. Wang, "ROS/p38/p53/Puma signaling pathway is involved in emodin-induced apoptosis of human colorectal cancer cells," International Journal of Clinical and Experimental Medicine, vol. 8, no. 9, pp. 15413-15422, 2015.

[28] M. Bhardwaj, N. H. Kim, S. Paul, R. Jakhar, J. Han, and S. C. Kang, "5-Hydroxy-7-methoxyflavone triggers mitochondrialassociated cell death via reactive oxygen species signaling in human colon carcinoma cells," Plos One, vol. 11, no. 4, article e0154525, 2016.

[29] J. Mathew, L. Galarneau, A. Loranger, S. Gilbert, and N. Marceau, "Keratin-protein kinase $\mathrm{C}$ interaction in reactive oxygen species-induced hepatic cell death through mitochondrial signaling," Free Radical Biology and Medicine, vol. 45, no. 4, pp. 413-424, 2008.

[30] R. Aziz, M. T. Rafiq, J. Yang et al., "Impact assessment of cadmium toxicity and its bioavailability in human cell lines (Caco-2 and HL-7702)," BioMed Research International, vol. 2014, Article ID 839538, 8 pages, 2014.

[31] L. H. Sun, M. Y. Lei, N. Y. Zhang et al., "Individual and combined cytotoxic effects of aflatoxin $\mathrm{B}_{1}$, zearalenone, deoxynivalenol and fumonisin $\mathrm{B}_{1}$ on BRL $3 \mathrm{~A}$ rat liver cells," Toxicon, vol. 95, pp. 6-12, 2015.

[32] A. Ferro, T. Mestre, P. Carneiro, I. Sahumbaiev, R. Seruca, and J. M. Sanches, "Blue intensity matters for cell cycle profiling in fluorescence DAPI-stained images," Laboratory Investigation, vol. 97, no. 5, pp. 615-625, 2017.

[33] X. L. Song, Y. J. Zhang, X. F. Wang et al., "Casticin induces apoptosis and G0/G1 cell cycle arrest in gallbladder cancer cells," Cancer Cell International, vol. 17, p. 9, 2017.

[34] X. Du, Z. Shi, Z. Peng et al., "Acetoacetate induces hepatocytes apoptosis by the ROS-mediated MAPKs pathway in ketotic cows," Journal of Cellular Physiology, vol. 232, no. 12, pp. 3296-3308, 2017.

[35] H. Draper and M. Hadley, "Malondialdehyde determination as index of lipid peroxidation," Methods in Enzymology, vol. 186, pp. 421-431, 1990.

[36] M. M. Amin, N. Rafiei, P. Poursafa et al., "Association of benzene exposure with insulin resistance, SOD, and MDA as markers of oxidative stress in children and adolescents," Environmental Science and Pollution Research, vol. 25, no. 34, pp. 34046-34052, 2018.

[37] H. M. Zhao, H. H. Ruan, and H. T. Li, "Progress in the research of GSH in cells," Chinese Science Bulletin, vol. 56, no. 28-29, pp. 3057-3063, 2011.

[38] S. Gao, X. Li, X. Ding, W. Qi, and Q. Yang, "Cepharanthine induces autophagy, apoptosis and cell cycle arrest in breast cancer cells," Cellular Physiology and Biochemistry, vol. 41, no. 4, pp. 1633-1648, 2017.
[39] X. Wu, D. Liu, X. Gao et al., "Inhibition of BRD4 suppresses cell proliferation and induces apoptosis in renal cell carcinoma," Cellular Physiology and Biochemistry, vol. 41, no. 5, pp. 1947-1956, 2017.

[40] P. Zou, Y. Xia, T. Chen et al., "Selective killing of gastric cancer cells by a small molecule targeting ROS-mediated ER stress activation," Molecular Carcinogenesis, vol. 55, no. 6, pp. 1073-1086, 2016.

[41] Y. Wu, M. Shamoto-Nagai, W. Maruyama, T. Osawa, and M. Naoi, "Phytochemicals prevent mitochondrial membrane permeabilization and protect SH-SY5Y cells against apoptosis induced by PK11195, a ligand for outer membrane translocator protein," Journal of Neural Transmission, vol. 124, no. 1, pp. 89-98, 2017.

[42] C. L. Yang, Y. G. Ma, Y. X. Xue, Y.-Y. Liu, H. Xie, and G.-R. Qiu, "Curcumin induces small cell lung cancer NCI-H446 cell apoptosis via the reactive oxygen speciesmediated mitochondrial pathway and not the cell death receptor pathway," DNA and Cell Biology, vol. 31, no. 2, pp. 139-150, 2012.

[43] M. B. Kastan, C. E. Canman, and C. J. Leonard, "P53, cell cycle control and apoptosis: implications for cancer," Cancer and Metastasis Reviews, vol. 14, no. 1, pp. 3-15, 1995.

[44] K. Ando, K. Hiroishi, T. Kaneko et al., "Perforin, Fas/Fas ligand, and TNF-alpha pathways as specific and bystander killing mechanisms of hepatitis C virus-specific human CTL," Journal of Immunology, vol. 158, no. 11, pp. 52835291, 1997.

[45] T. Patel and G. J. Gores, "Apoptosis and hepatobiliary disease," Hepatology, vol. 21, no. 6, pp. 1725-1741, 1995.

[46] S. W. Ip, Y. S. Weng, S. Y. Lin et al., "The role of $\mathrm{Ca}+2$ on rhein-induced apoptosis in human cervical cancer Ca Ski cells," Anticancer Research, vol. 27, no. 1A, pp. 379-389, 2007.

[47] D. Pessayre, A. Mansouri, A. Berson, and B. Fromenty, "Mitochondrial involvement in drug-induced liver injury," in Adverse Drug Reactions, vol. 196 of Handbook of Experimental Pharmacology, pp. 311-365, Springer, Berlin, Heidelberg, 2010.

[48] A. Gross, J. M. Mcdonnell, and S. J. Korsmeyer, "BCL-2 family members and the mitochondria in apoptosis," Genes and Development, vol. 13, no. 15, pp. 1899-1911, 1999.

[49] W. W. Wong and H. Puthalakath, "Bcl-2 family proteins: the sentinels of the mitochondrial apoptosis pathway," IUBMB Life, vol. 60, no. 6, pp. 390-397, 2008.

[50] Q. Wang, H. Du, G. Geng et al., "Matrine inhibits proliferation and induces apoptosis via BID-mediated mitochondrial pathway in esophageal cancer cells," Molecular Biology Reports, vol. 41, no. 5, pp. 3009-3020, 2014.

[51] D. R. Green and F. Llambi, "Cell death signaling," Cold Spring Harbor Perspectives in Biology, vol. 7, no. 12, article a006080, 2015.

[52] B. E. Oyinloye, A. F. Adenowo, and A. P. Kappo, "Reactive oxygen species, apoptosis, antimicrobial peptides and human inflammatory diseases," Pharmaceuticals, vol. 8, no. 2, pp. 151-175, 2015.

[53] Y. Song, X. Li, Y. Li et al., "Non-esterified fatty acids activate the ROS-p38-p53/Nrf2 signaling pathway to induce bovine hepatocyte apoptosis in vitro," Apoptosis, vol. 19, no. 6, pp. 984-997, 2014.

[54] D. Li, E. Ueta, T. Kimura, T. Yamamoto, and T. Osaki, "Reactive oxygen species (ROS) control the expression of Bcl-2 
family proteins by regulating their phosphorylation and ubiquitination," Cancer Science, vol. 95, no. 8, pp. 644-650, 2004.

[55] K. Kannan and S. K. Jain, "Oxidative stress and apoptosis," Pathophysiology, vol. 7, no. 3, pp. 153-163, 2000.

[56] Y. Wang, S. H. Guo, X. J. Shang et al., "Triptolide induces Sertoli cell apoptosis in mice via ROS/JNK-dependent activation of the mitochondrial pathway and inhibition of Nrf2-mediated antioxidant response," Acta Pharmacologica Sinica, vol. 39, no. 2, pp. 311-327, 2018.

[57] Y. M. Chung, Y. S. Bae, and S. Y. Lee, "Molecular ordering of ROS production, mitochondrial changes, and caspase activation during sodium salicylate-induced apoptosis," Free Radical Biology and Medicine, vol. 34, no. 4, pp. 434-442, 2003.

[58] M. R. Bennett, "Reactive Oxygen Species and Death Oxidative DNA Damage in Atherosclerosis," Circulation Research, vol. 88, no. 7, pp. 648-650, 2001.

[59] K. H. Vousden and X. Lu, "Live or let die: the cell's response to p53," Nature Reviews Cancer, vol. 2, no. 8, pp. 594-604, 2002.

[60] H. Liu, Q. Luo, H. Cui et al., "Sodium fluoride causes hepatocellular S-phase arrest by activating ATM-p53-p21 and ATRChk1-Cdc25A pathways in mice," Oncotarget, vol. 9, no. 4, pp. 4318-4337, 2018.

[61] B. Zhao, B. Li, S. Bai et al., "Effects of matrine on proliferation and apoptosis of cultured retinoblastoma cells," Graefes Archive for Clinical and Experimental Ophthalmology, vol. 250, no. 6, pp. 897-905, 2012.

[62] M. Pagano, R. Pepperkok, F. Verde, W. Ansorge, and G. Draetta, "Cyclin A is required at two points in the human cell cycle," The EMBO Journal, vol. 11, no. 3, pp. 961-971, 1992.

[63] T. Wang, D. Xia, N. Li et al., "Bone marrow stromal cellderived growth inhibitor inhibits growth and migration of breast cancer cells via induction of cell cycle arrest and apoptosis," Journal of Biological Chemistry, vol. 280, no. 6, pp. 4374-4382, 2005.

[64] J. S. Fridman and S. W. Lowe, "Control of apoptosis by p53," Oncogene, vol. 22, no. 56, pp. 9030-9040, 2003. 


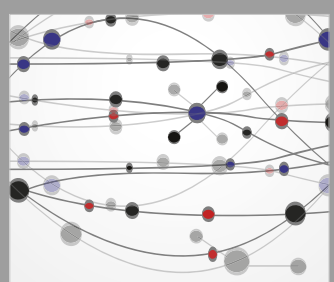

The Scientific World Journal
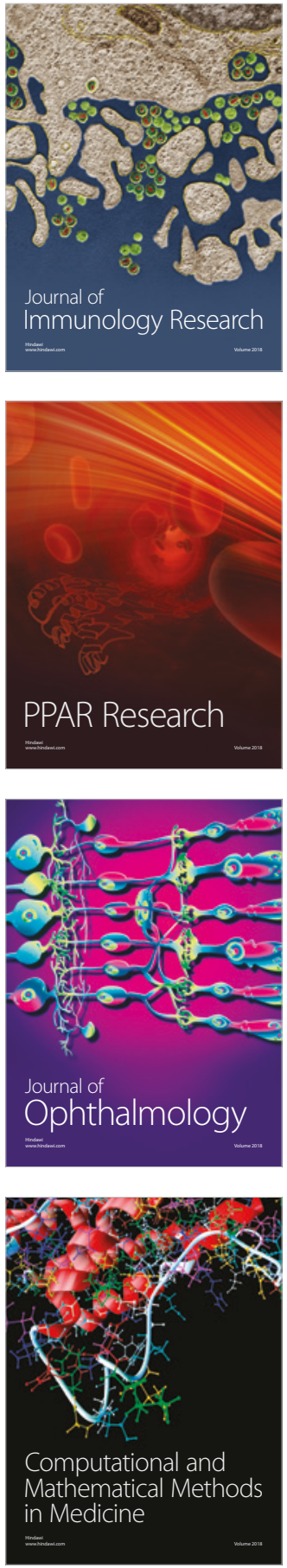

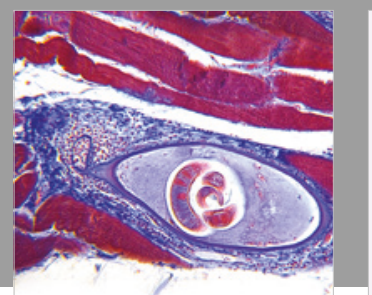

Gastroenterology Research and Practice

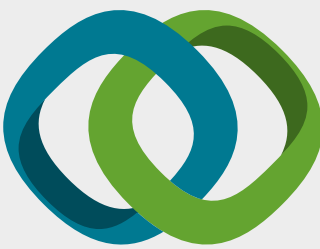

\section{Hindawi}

Submit your manuscripts at

www.hindawi.com
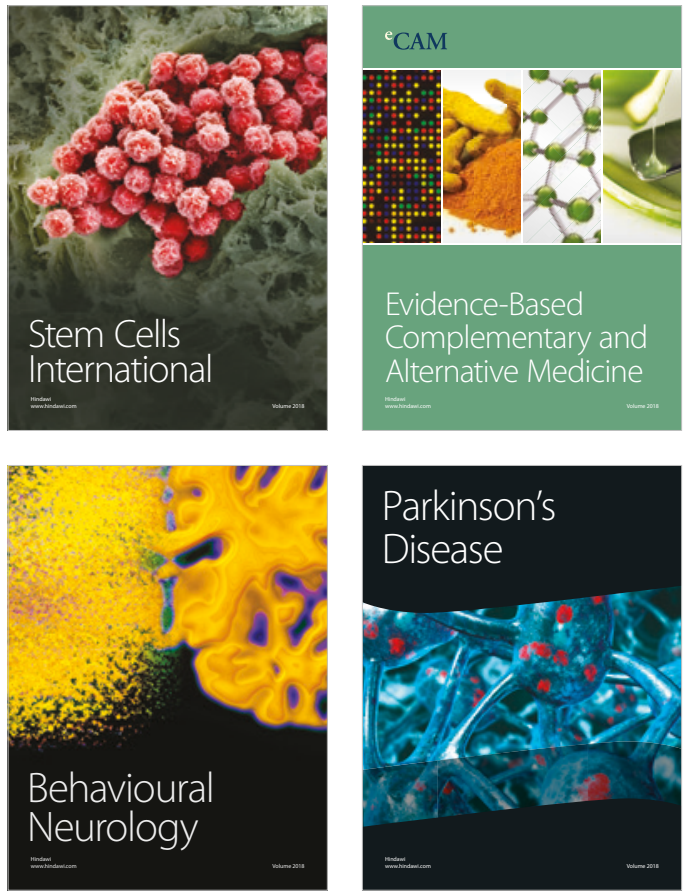

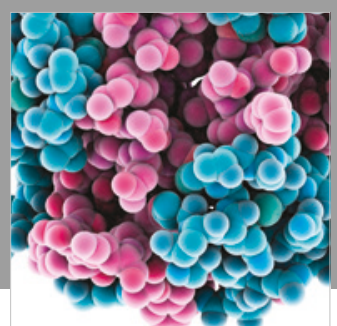

ournal of

Diabetes Research

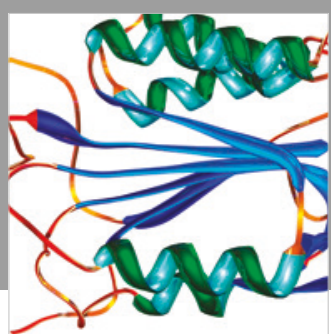

Disease Markers
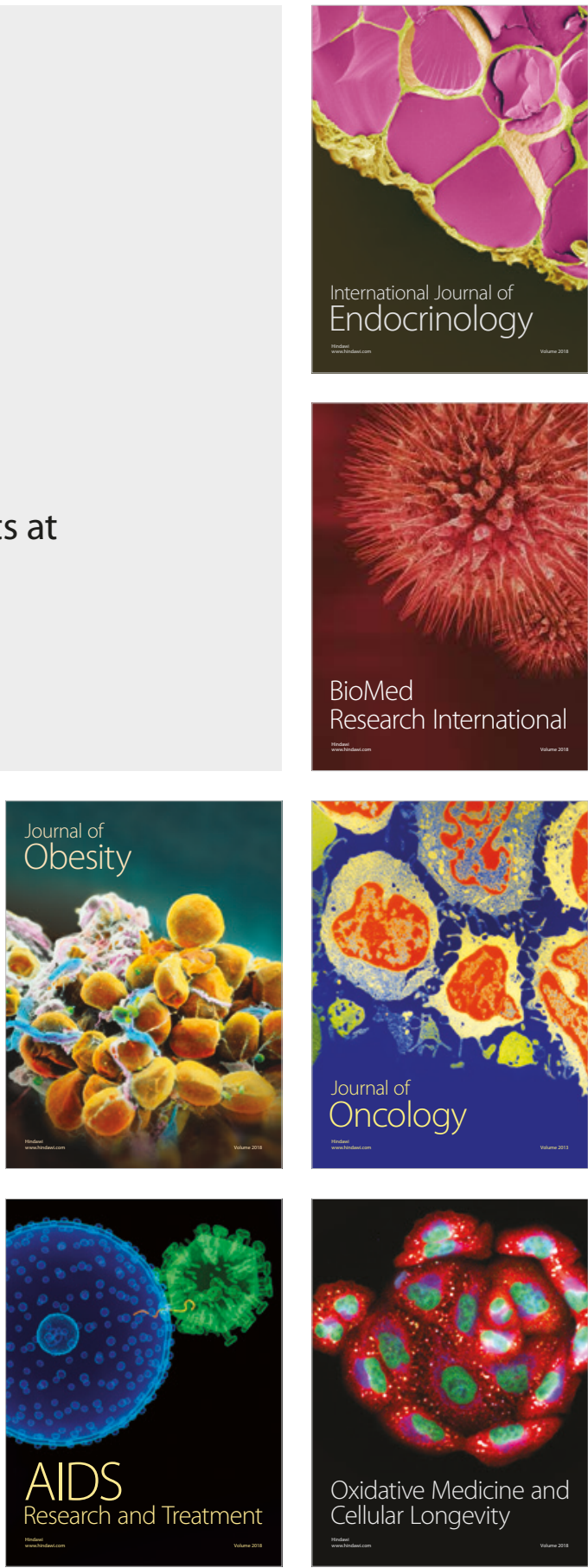